Review

\title{
Currently Used Laboratory Methodologies for Assays Detecting PD-1, PD-L1, PD-L2 and Soluble PD-L1 in Patients with Metastatic Breast Cancer
}

\author{
Seri Jeong ${ }^{1}{ }^{\mathbb{D}}$, Nuri Lee ${ }^{1}$, Min-Jeong Park ${ }^{1} \mathbb{D}$, Kibum Jeon $^{2}$ and Wonkeun Song ${ }^{1, *}$ \\ 1 Department of Laboratory Medicine, Kangnam Sacred Heart Hospital, Hallym University College of \\ Medicine, Seoul 07440, Korea; hehebox73@hallym.or.kr (S.J.); nurilee822@hallym.or.kr (N.L.); \\ mjpark@hallym.or.kr (M.-J.P.) \\ 2 Department of Laboratory Medicine, Hangang Sacred Heart Hospital, Hallym University College of \\ Medicine, Seoul 07440, Korea; pourmythe45@hallym.or.kr \\ * Correspondence: swonkeun@hallym.or.kr; Tel.: +82-2-829-5259
}

Citation: Jeong, S.; Lee, N.; Park, M.-J.; Jeon, K.; Song, W. Currently Used Laboratory Methodologies for Assays Detecting PD-1, PD-L1, PD-L2 and Soluble PD-L1 in Patients with Metastatic Breast Cancer. Cancers 2021, 13, 5225. https://doi.org/ $10.3390 /$ cancers 13205225

Academic Editor: Vesna Bjelic-Radisic

Received: 12 August 2021

Accepted: 13 October 2021

Published: 18 October 2021

Publisher's Note: MDPI stays neutral with regard to jurisdictional claims in published maps and institutional affiliations.

Copyright: (c) 2021 by the authors. Licensee MDPI, Basel, Switzerland. This article is an open access article distributed under the terms and conditions of the Creative Commons Attribution (CC BY) license (https:// creativecommons.org/licenses/by/ $4.0 /)$.
Simple Summary: Several methods targeting the programmed death protein-1 (PD-1) axis have been developed and evaluated for the detection of immune checkpoint levels that are strongly involved in immunotherapy for patients with metastatic breast cancer. Variations in different assays used in diverse studies have affected their result interpretation and clinical utility. When applying these assays to the laboratory, a comprehensive understanding of the characteristics of them should be recognized. We reviewed applied laboratory techniques for detecting PD-1, PD-ligand (L)1, PD-L2, and soluble PD-L1, which are important for selecting metastatic cancer patients for immunotherapy. Advances in methodologies according to the epoch are also investigated to gain insight into immunologic techniques and to facilitate appropriate laboratory settings for evaluating the PD- 1 axis status, which are useful for estimating outcomes and planning patient-tailored immunotherapy strategies.

Abstract: Approximately $20 \%$ of breast cancer (BC) patients suffer from distant metastasis. The incidence and prevalence rates of metastatic $\mathrm{BC}$ have increased annually. Immune checkpoint inhibitors are an emerging area of treatment, especially for metastatic patients with poor outcomes. Several antibody drugs have been developed and approved for companion testing of the programmed death protine-1 (PD-1) axis. We reviewed currently used laboratory methodologies for assays determining PD-1 axis to provide a comprehensive understanding of principles, advantages, and drawbacks involved in their implementation. The most commonly used method is immunohistochemistry $(92.9 \%)$ for PD-L1 expression using tissue samples $(96.4 \%)$. The commonly used anti-PD-L1 antibody clone were commercially available 22C3 (30.8\%), SP142 (19.2\%), SP263 (15.4\%), and E1L3N (11.5\%). Enzyme-linked immunosorbent assay and electrochemiluminescent immunoassay that target soluble PD-ligand (L)1 were developed and popularized in 2019-2021, in contrast to 2016-2018. Easy accessibility and non-invasiveness due to the use of blood samples, quantitative outputs, and relatively rapid turnaround times make them more preferable. Regarding scoring methods, a combination of tumor and immune cells (45.5\% in 2016-2018 to $57.1 \%$ in 2019-2021) rather than each cell alone became more popular. Information about antibody clones, platforms, scoring methods, and related companion drugs is recommended for reporting PD-L1 expression.

Keywords: breast cancer; checkpoint inhibitor; immunotherapy; metastasis; PD-1; PD-L1; PD-L2; programmed cell death; soluble PD-L1 


\section{Introduction}

\subsection{Epidemiology of Metastatic Breast Cancer}

Among women, breast cancer (BC) is the most commonly diagnosed cancer and the second leading cause of cancer-related deaths in major countries [1,2]. According to the Global Cancer Observatory, 2,261,419 new breast cancer cases and 684,996 cancer-related deaths were estimated to occur worldwide in 2020 [3]. The BC incidence rates surpassed other cancers in both developed and developing countries [4,5]. The rates were highest in regions such as Australia, New Zealand, western and northern Europe, and North and South America [5]. In transitioning countries, the BC rates in South America [6], Africa [7], and high-income Asian countries [8] were found to rise rapidly. Women with BC living in transitioning countries have $17 \%$ higher mortality rates than those in transitioned nations [5]. This variability is related to sociocultural and/or dramatic environmental changes, including nutrition, hormone intake, lactation, and reproductive patterns [9]. Improved awareness of $\mathrm{BC}$ and clinical examination has led to its increased detection through mammographic screening. Due to the development of tumor markers and effective treatment, mortality rates in transitioned countries have decreased [10,11]. However, approximately $20 \%$ of $B C$ patients suffer from distant metastasis within the first 5 years [12] The incidence rate of metastatic BC in the United States increased by $2.5 \%$ annually from 2001 to 2011 according to population-based cancer data [13]. The number of women living with metastatic BC increased by $4 \%$ from $1990-2000,17 \%$ from $2000-2010$, and is projected to increase by $31 \%$ from $2010-2020$ according to Surveillance, Epidemiology, and End Results (SEER) registries [14]. Patients with metastatic BC have a poor outcome, with an overall 5-year survival rate of $27 \%$ [13].

\subsection{Immunotherapy and Immune Checkpoint of Metastatic $B C$}

Most patients with metastatic $\mathrm{BC}$ received palliative and non-curative treatment. About $56 \%$ of patients were treated with radiation and chemotherapy alone, and $26 \%$ of them received no treatment or partial hormonal therapy [13]. However, targeted systemic treatments for $\mathrm{BC}$, particularly for estrogen receptor (ER), progesterone receptor (PR), and human epidermal growth factor receptor 2 (HER2)-positive status [15], have improved survival for the metastatic disease over the past three decades [16]. Based on the SEER database, the 5-year relative survival rate had a 2-fold increase from $18 \%$ to $36 \%$ for patients diagnosed with de novo metastatic BC between 1992-1994 and 2005-2012, respectively. In the Netherlands, the 10-year overall survival rate increased from $6 \%$ to $9 \%$ for metastatic $B C$ [17]. A previous meta-analysis also demonstrated that median survival increased for recurrent and de novo metastatic BC between 1990-2010 [16]. The survival rate of women with metastatic BC differed according to the ER status. For ER-positive patients, median survival increased from 32 to 57 months, and for ER-negative women from 14 to 33 months, reflecting the effectiveness of hormonal therapy. However, $\mathrm{BC}$ with negativity for ER, PR, and lack of amplification/overexpression of HER2, occupying about $10-20 \%$, remained as an aggressive histologic subtype with worse outcomes $[18,19]$. Chemotherapies such as anthracyclines, taxanes, capecitabine, eribulin, and carboplatin are frequently used and recommended by the National Comprehensive Cancer Network (NCCN) [20] and the European School of Oncology-European Society for Medical Oncology (ESO-ESMO) [21] guidelines for patients with triple-negative BC. However, chemotherapies are generally related to unfavorable adverse events, and more so when combined, resulting in treatment discontinuation. Moreover, combining treatments did not prolong overall survival rates compared with monotherapies [22]. Therefore, the NCCN and ESO-ESMO guidelines $[20,21]$ recommend the sequential use of single-agent chemotherapy for the treatment of metastatic $\mathrm{BC}$, including the triple-negative subtype. In the recently published version (NCCN Version 3.2020 and 5th ESO-ESMO) of these guidelines [20,21], immunotherapy drugs are included as first-line therapy for programmed death ligand-1 (PD-L1)-positive metastatic BC. Immune checkpoint inhibitors are an emerging area of BC therapy, especially for patients with triple negative subtype. The PD-L1 checkpoint inhibitor atezolizumab, 
in combination with paclitaxel, has been related to prolong progression-free survival in a phase III trial (Impassion 130) [23] and has recently been granted approval by the US Food and Drug Administration (FDA). Furthermore, several novel monoclonal antibodies including pembrolizumab and nivolumab targeting programmed cell death protein-1 (PD-1) and durvalumab and avelumab targeting PD-L1 have been approved [24,25]. Furthermore, clinical trials evaluating combinations of immunotherapies and targeted therapies for all subtypes of BC have been conducted [26].

These recent investigations highlight the importance of testing immune checkpoint levels to select patients expecting greater benefit from these immunotherapies. Moreover, the drug approval process requires determination of PD-L1 expression for a combination of immune checkpoint inhibitors $[27,28]$. Upregulation of inhibitory immune checkpoint pathways by tumor cells (TC) and/or immune cells (IC) within the tumor microenvironment and the PD-1 axis enables TC to escape the immune system [29]. When PD-1 expressed on IC is activated by its ligands, PD-L1 or PD-L2, it attenuates lymphocyte activation and promotes the development of functional regulatory $\mathrm{T}$ cells, leading to the inhibition of the immune response [29,30]. As many tumors use this strategy to escape the immune system, the PD-1 signaling pathway has become an important therapeutic target in the field of breast cancer [31].

\subsection{Aims of This Review}

Several methods for the PD- 1 axis have been developed and evaluated for the detection of immune checkpoint levels that are strongly involved in immunotherapy of patients with metastatic BC [25,31]. Variations in the assays used in diverse studies have affected their results and clinical utility. When applying these assays to the laboratory, a comprehensive understanding of the characteristics of them is required. Studies focusing on laboratory techniques for evaluating PD-L1 and related markers, including PD-1, PD-L2, and soluble PD-L1, have been rarely published. Therefore, our review describes several immunological assays for these immune checkpoints, the main determinants of immunotherapy in metastatic BC. Advances in methodologies according to the epoch have also been investigated based on published articles to provide an insight into the techniques and facilitate appropriate laboratory settings for evaluating PD-1 axis status, which is useful for estimating outcomes and planning patient-tailored immunotherapy strategies.

\section{Sample Type}

\subsection{Tissue Sample}

The sample types obtained from women with metastatic BC for testing PD-1 axis status are presented in Table 1 . Twenty-eight of the studies were from three recently published systematic reviews and meta-analyses $[22,32,33]$ and manual searching for the PD- 1 axis in metastatic BC. The additional search strategy terms for PD-L2 and soluble PD-1 axis are as follows: (((Breast cancer[MeSH Terms]) OR ((breast) AND (cancer* OR tumor* OR tumour* OR carcinoma* OR neoplasm* OR carcinogen* OR malignan*))) AND (metastat* OR advance* OR second* OR recurren* OR inoperab* OR disseminat* OR incur*)) AND (pd-12[Title/Abstract])) and (((Breast cancer[MeSH Terms]) OR ((breast) AND (cancer* OR tumor* OR tumour* OR carcinoma* OR neoplasm* OR carcinogen* OR malignan*))) AND (metastat ${ }^{*}$ OR advance* OR second ${ }^{*}$ OR recurren* OR inoperab* OR disseminat* OR incur*)) AND ((soluble pd-1[Title/Abstract]) OR soluble pd-11[Title/Abstract]) OR soluble pd-12[Title/Abstract])). Relevant articles with specific immunoassays for the PD-1 axis were manually checked. The most commonly utilized sample type was tissues $(96.4 \%)$, including formalin-fixed paraffin-embedded (FFPE) tissues and freshly biopsied or surgically resected tissues (Figure 1). Archival FFPE tissues are a powerful resource for testing the PD-1 axis [34,35]. In particular, initial pre-metastatic tissue from metastatic BC patients for investigation was mostly FFPE because of its preservability [32]. However, perfect staining results cannot be guaranteed because of the possibility of tissue degradation and antigen loss in archived tissues over time. Therefore, a clinical trial included only biopsied or 
surgical specimens collected within 90 days [36]. Biopsies or surgically excised specimens should be fixed in neutral-buffered formalin for 6-72 h, depending on the sample size [37]. It is recommended that whole-slide sections with $2.5-4 \mu \mathrm{m}$ thickness are cut from representative areas of the FFPE tumor tissue. The thickness depends on laboratory settings, such as targeting materials and commercially available autostainers. In general, the tissue sections were de-paraffinized with xylene and underwent rehydration and antigen retrieval for PD-1, PD-L1, and PD-L2 [34,35]. Tonsil tissue is recommended as a cost-effective positive control because the tonsil parenchyma contains PD-L1-positive immune cells.

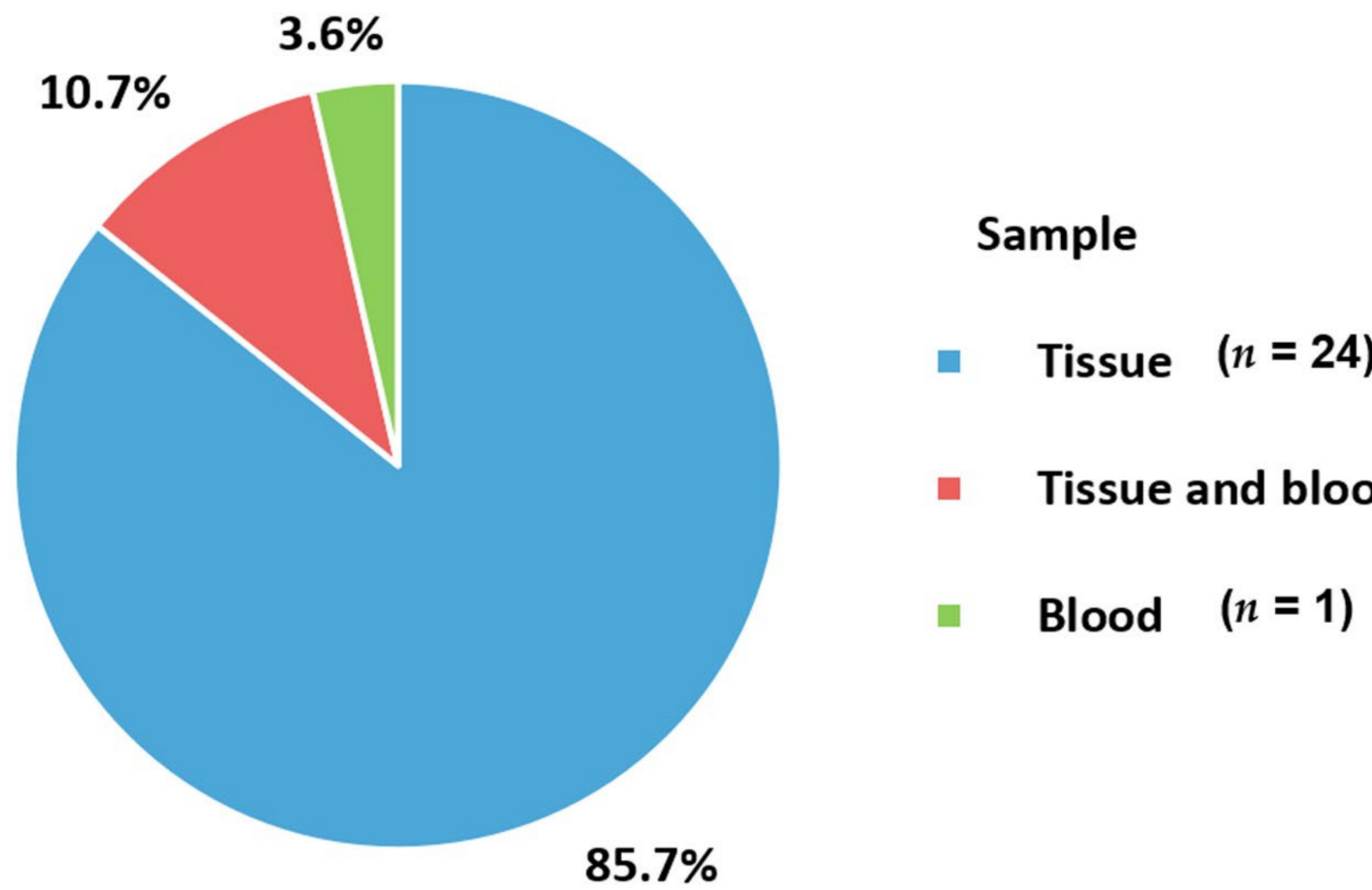

Figure 1. Sample type for identifying PD-1 axis. 
Table 1. Main characteristics and immunological assays of studies for PD-1, PD-L1, and PD-L2 in metastatic breast cancer.

\begin{tabular}{|c|c|c|c|c|c|c|c|c|c|}
\hline First Author (Year) & Tumor Type $(n)$ & Sample Type & Target & Antibody Clone & Detection Method & Detection System/Assay Producer & Scoring Methods & Cut-Off & Study Country \\
\hline Adams (2019) [38,39] & TNmBC (170) & $\begin{array}{l}\text { Archival and/or } \\
\text { freshly collected } \\
\text { tumor tissue }\end{array}$ & PD-L1 & $22 \mathrm{C} 3$ & $\mathrm{IHC}$ & $\begin{array}{l}\text { PD-L1 IHC 22C3 pharmDx (Dako, } \\
\text { Agilent, Carpinteria, CA, USA) }\end{array}$ & $\begin{array}{l}\text { Combined positive } \\
\text { score }\end{array}$ & 0.01 & Multi-national \\
\hline Adams (2019) [38] & TNmBC (84) & $\begin{array}{l}\text { Archival and /or } \\
\text { freshly collected } \\
\text { tumor tissue }\end{array}$ & PD-L1 & $22 \mathrm{C} 3$ & $\mathrm{IHC}$ & $\begin{array}{l}\text { PD-L1 IHC 22C3 pharmDx (Dako, } \\
\text { Agilent, Carpinteria, CA, USA) }\end{array}$ & $\begin{array}{l}\text { Combined positive } \\
\text { score }\end{array}$ & 0.01 & Multi-national \\
\hline Adams (2018) [39] & TNmBC (33) & $\begin{array}{l}\text { Archival and/or } \\
\text { freshly collected } \\
\text { tumor tissue }\end{array}$ & PD-L1 & SP142 & $\mathrm{IHC}$ & $\begin{array}{l}\text { VENTANA PD-L1 (SP142) assay (Ventana } \\
\text { Medical System, Roche, Basel, } \\
\text { Switzerland) }\end{array}$ & TC and IC & $1 \%$ and $1 \%$ & USA \\
\hline Alves (2019) [40] & $\mathrm{mBC}(41)$ & FFPE & PD-L1 & SP142 & $\mathrm{IHC}$ & $\begin{array}{l}\text { Anti-human PD-L1 rabbit monoclonal } \\
\text { (clone SP142, dilution: ready to use; } \\
\text { Ventana, Tucson, AZ, USA) }\end{array}$ & TC & 0.01 & Portugal \\
\hline Dirix (2018) [36] & $\begin{array}{l}\text { Any subtype } \\
\mathrm{mBC}(168)\end{array}$ & $\begin{array}{l}\text { surgical specimen } \\
\text { collected within } \\
90 \text { days })\end{array}$ & PD-L1 & 73-10 & $\mathrm{IHC}$ & $\begin{array}{l}\text { PD-L1 IHC 73-10 pharmDx (Dako, } \\
\text { Carpinteria, CA, USA) }\end{array}$ & TC and IC & $1 \%$ and $10 \%$ & Europe and USA \\
\hline Domchek (2020) [42] & $\begin{array}{l}\text { BRCA-mutated } \\
\mathrm{mBC}(32)\end{array}$ & FFPE/serum & $\begin{array}{l}\text { PD-L1/soluble } \\
\text { PD-L1 }\end{array}$ & $\begin{array}{l}\text { SP263/2.7 A4 } \\
\text { and } 130021\end{array}$ & $\begin{array}{l}\text { IHC and ECL } \\
\text { immunoassay }\end{array}$ & $\begin{array}{l}\text { VENTANA PD-L1 (SP263) assay (Roche, } \\
\text { Basel Switzerland)/Anti-PD-L1 capture } \\
\text { antibody clone 2.7 A4 (MedImmune) and } \\
\text { anti-PD-L1 primary detection antibody } \\
\text { clone 130021 (R\&D Systems) }\end{array}$ & $\begin{array}{l}\text { TC and } \\
\text { IC/concentration of } \\
\text { soluble PD-L1 }\end{array}$ & $\begin{array}{c}1 \% \text { and } \\
1 \% / 15.6 \mathrm{pg} / \mathrm{mL}\end{array}$ & Multi-national \\
\hline Duchnowska (2016) [43] & Brain mBC (84) & FFPE & $\begin{array}{l}\text { PD-1/PD- } \\
\text { L1/PD-L2 }\end{array}$ & NR & $\mathrm{IHC}$ & $\begin{array}{c}\text { NBP1-88104 (cytoplasmic) (Novus, } \\
\text { Centennial, CO, USA)/AHP2128 } \\
\text { (membranous/cytoplasmic) (AbD Serotec, } \\
\text { Hercules, CA, USA)/AF1224 } \\
\text { (membranous/cytoplasmic) (R\&D } \\
\text { systems, Minneapolis, MN, USA) }\end{array}$ & $\begin{array}{l}\text { Lymphoid } \\
\text { cells/semiquantitative } \\
\text { staining H-score/ } \\
\text { semiquantitative } \\
\text { staining H-score }\end{array}$ & $1 \% / \mathrm{NR} / \mathrm{NR}$ & Poland \\
\hline Emens (2020) [44] & $\begin{array}{l}\text { HER2-positive } \\
\text { mBC (132) }\end{array}$ & $\begin{array}{l}\text { Pretreatment } \\
\text { tumor tissue }\end{array}$ & PD-L1 & SP142 & $\mathrm{IHC}$ & $\begin{array}{l}\text { VENTANA PD-L1 (SP142) assay (Ventana } \\
\text { Medical System, Roche, Basel, } \\
\text { Switzerland) }\end{array}$ & IC & 0.01 & Multi-national \\
\hline Emens (2019) [45] & TNmBC (115) & $\begin{array}{l}\text { Pretreatment } \\
\text { tumor tissue }\end{array}$ & PD-L1 & SP142 & $\mathrm{IHC}$ & $\begin{array}{l}\text { VENTANA PD-L1 (SP142) assay (Ventana } \\
\text { Medical System, Roche, } \\
\text { Basel, Switzerland) }\end{array}$ & TC and IC & $1 \%$ and $1 \%$ & Europe and USA \\
\hline Erol (2019) [46] & $\begin{array}{l}\mathrm{mBC}(47) / \\
\mathrm{mBC}(23)\end{array}$ & FFPE & $\begin{array}{l}\text { PD-L1/PD-L1 } \\
\text { methylation }\end{array}$ & E1L3N & $\begin{array}{l}\text { IHC/quantitative } \\
\text { real-time PCR }\end{array}$ & $\begin{array}{l}\text { E1L3N monoclonal antibody (Cell } \\
\text { Signaling Technology, Danvers, MA, } \\
\text { USA)/EZ DNA Methylation-Gold kit } \\
\text { (Zymo Research, Irvine, CA USA) }\end{array}$ & TC & 0.05 & Turkey \\
\hline $\operatorname{Han}(2021)[47]$ & $\mathrm{mBC}(208)$ & FFPE/plasma & $\begin{array}{l}\text { PD-L1/ } \\
\text { soluble } \\
\text { PD-L1 }\end{array}$ & ab58810 & IHC/ELISA & $\begin{array}{c}\text { clone ab58810 (Abcam, Paris, } \\
\text { France)/PDCD1LG1 ELISA kit (USCN } \\
\text { Life Science, Wuhan, China) } \\
\text { OualTek immunohistochemistry assay }\end{array}$ & $\begin{array}{l}\text { TC/concentration of } \\
\text { soluble PD-L1 }\end{array}$ & $1 \% / 8.774 \mathrm{ng} / \mathrm{mL}$ & China \\
\hline Loi (2019) [48] & $\begin{array}{l}\text { HER2-positive } \\
\text { mBC (58) }\end{array}$ & FFPE & PD-L1 & $22 \mathrm{C} 3$ & $\mathrm{IHC}$ & $\begin{array}{l}\text { (QualtTek Molecular Laboratories, Santa } \\
\text { Barbara, CA, USA) and Dako IHC 22C3 } \\
\text { pharmDx } Q^{2} \text { Solutions assay } \\
\text { (Q } Q^{2} \text { Solutions, West Lothian, UK) }\end{array}$ & TC and TCIC & $1 \%$ and $1 \%$ & Multi-national \\
\hline
\end{tabular}


Table 1. Cont.

\begin{tabular}{|c|c|c|c|c|c|c|c|c|c|}
\hline First Author (Year) & Tumor Type $(n)$ & Sample Type & Target & Antibody Clone & Detection Method & Detection System/Assay Producer & Scoring Methods & Cut-Off & Study Country \\
\hline Manson (2019) [49] & $\begin{array}{l}\mathrm{mBC}(67) / \\
\mathrm{mBC}(83)\end{array}$ & FFPE & PD-L1/PD-1 & SP263 & $\mathrm{IHC}$ & $\begin{array}{l}\text { anti-PD-L1 rabbit monoclonal antibody } \\
\text { (741-4905 (clone sp263, dilution Ventana } \\
\text { ready to use; Ventana Medical Systems, } \\
\text { Tucson, AZ, USA))/anti-PD-1 mouse } \\
\text { monoclonal antibody (ab52587 (NAT105, } \\
\text { dilution 1:50, Abcam, Cambridge, UK)) }\end{array}$ & TC and IC/IC & $>0 \%$ & Netherland \\
\hline Mitchell (2018) [50] & TNmBC (39) & Tissue & PD-L1 & $22 \mathrm{C} 3$ & $\mathrm{IHC}$ & $\begin{array}{l}\text { PD-L1 IHC 22C3 pharmDx assay (Agilent, } \\
\text { Carpinteria, CA, USA) }\end{array}$ & $\begin{array}{l}\text { Combined } \\
\text { positive score }\end{array}$ & 0.01 & USA \\
\hline Nanda (2016) [51] & TNmBC (27) & FFPE & PD-L1 & $22 \mathrm{C} 3$ & $\mathrm{IHC}$ & $\begin{array}{c}\text { 22C3 antihuman PD-L1 antibody (Merck } \\
\text { \& Co., Kenilworth, NJ, UK) }\end{array}$ & $\mathrm{TC}$ & 0.01 & USA \\
\hline Ogiya (2016) [52] & $\begin{array}{l}\text { HER2-positive } \\
\text { mBC (14)/ } \\
\operatorname{TNmBC}(11)\end{array}$ & FFPE & $\begin{array}{l}\text { PD-L1 } \\
\text { and PD-L2 }\end{array}$ & ab58810/XX19 & $\mathrm{IHC}$ & $\begin{array}{l}\text { Anti-PD-L1 (polyclonal, ab58810; Abcam, } \\
\text { Cambridge, MA, USA)/ anti-Pdcd-1L22 } \\
\text { (PD-L2, clone XX19; Santa Cruz } \\
\text { Biotechnology, Dallas, TX, USA) }\end{array}$ & Lymphocyte staining & 0.1 & Japan \\
\hline $\begin{array}{l}\text { Quintela-Fandino } \\
\text { (2020) [34] }\end{array}$ & $\begin{array}{l}\text { HER2-negative } \\
\text { mBC (24) }\end{array}$ & FFPE & PD-L1 & SP263 & $\mathrm{IHC}$ & $\begin{array}{l}\text { Ventana SP263 assay (Ventana Medical } \\
\text { Systems, Inc., Oro Valley, AZ, USA). }\end{array}$ & NR & 0.01 & Spain \\
\hline Rugo (2018) [53] & $\begin{array}{l}\text { ER-positive/ } \\
\text { HER2-negative } \\
\text { mBC (25) }\end{array}$ & $\begin{array}{l}\text { FFPE (An archival } \\
\text { or newly obtained } \\
\text { core or excisional } \\
\text { biopsy specimen } \\
\text { from a } \\
\text { nonirradiated } \\
\text { tumor lesion) }\end{array}$ & PD-L1 & $22 \mathrm{C} 3$ & $\mathrm{IHC}$ & $\begin{array}{l}\text { Prototype assay (QualTek Molecular } \\
\text { Laboratories, Goleta, CA, USA) and the } \\
\text { 22C3 antibody (Merck \& Co. Inc., } \\
\text { Kenilworth, NJ, USA) }\end{array}$ & $\begin{array}{c}\text { Tumor } \\
\text { proportion score }\end{array}$ & 0.01 & Multi-national \\
\hline Santa-Maria (2018) [54] & $\begin{array}{l}\text { ER-positive or } \\
\text { TNmBC (18) }\end{array}$ & Biopsies & $\begin{array}{l}\text { PD-L1 } \\
\text { and PD-L2 }\end{array}$ & NA & $\begin{array}{l}\text { Quantitative } \\
\text { real-time PCR }\end{array}$ & $\begin{array}{l}\text { TaqMan probes (Life Technologies, Foster } \\
\text { City, CA, USA) and ABI ViiA } 7 \text { system } \\
\text { (Applied Biosystems, } \\
\text { Foster City, CA, USA) }\end{array}$ & NA & NA & USA \\
\hline Schmid (2018) [23] & TNmBC (451) & $\begin{array}{l}\text { FFPE or fresh } \\
\text { pretreatment } \\
\text { relapsed-disease } \\
\text { tumor tissue }\end{array}$ & PD-L1 & SP142 & $\mathrm{IHC}$ & $\begin{array}{l}\text { VENTANA PD-L1 (SP142) assay (Ventana } \\
\text { Medical System, Roche, } \\
\text { Basel, Switzerland) }\end{array}$ & IC & 0.01 & UK and USA \\
\hline Schott (2017) [55] & $\mathrm{mBC}(17)$ & $\begin{array}{l}\text { Circulating } \\
\text { epithelial } \\
\text { tumor cells }\end{array}$ & $\begin{array}{l}\text { PD-L1/ } \\
\text { PD-L2 }\end{array}$ & 29E.2A3/176611 & $\begin{array}{l}\text { Immunofluorescence } \\
\text { analysis }\end{array}$ & $\begin{array}{c}\text { Anti-human PD-L1 } \\
\text { phycoerythrin-conjugated antibody } \\
\text { (clone 29E.2A3, BioLegend, San Diego, } \\
\text { USA)/anti-human PD-L2 Alexa Fluor } \\
350 \text { conjugated antibody (clone 176611, } \\
\text { novus biologicals, Littleton, CO, USA) }\end{array}$ & $\begin{array}{l}\text { Total number of } \\
\text { circulating epithelial } \\
\text { tumor cells }\end{array}$ & NA & Germany \\
\hline Szekely (2018) [56] & $\begin{array}{l}\mathrm{mBC}(87) / \\
\mathrm{mBC}(27)\end{array}$ & $\begin{array}{l}\text { Surgically resected } \\
\text { tissue and FFPE }\end{array}$ & PD-L1 & E1L3N & $\mathrm{IHC}$ & $\begin{array}{l}\text { (Cell Signaling, Danvers, MA, Technology, } \\
\text { USA)/Nanostring PanCancer Immune } \\
\text { Profiling assay (Nanostring Technologies, } \\
\text { Inc., Seattle, WA, USA). }\end{array}$ & TC & 0.01 & Europe and USA \\
\hline Tawfik (2018) [57] & $\mathrm{mBC}(41)$ & $\begin{array}{l}\text { Core needle } \\
\text { biopsy, excision, } \\
\text { and FFPE }\end{array}$ & PD-L1 & SP263 & $\mathrm{IHC}$ & $\begin{array}{l}\text { VENTANA PD-L1 (SP263) assay (Roche } \\
\text { Ventana Medical Systems, } \\
\text { Tucson, AZ, USA) }\end{array}$ & TC and IC & $1 \%$ and $10 \%$ & USA \\
\hline
\end{tabular}


Table 1. Cont.

\begin{tabular}{|c|c|c|c|c|c|c|c|c|c|}
\hline First Author (Year) & Tumor Type $(n)$ & Sample Type & Target & Antibody Clone & Detection Method & Detection System/Assay Producer & Scoring Methods & Cut-Off & Study Country \\
\hline Tolaney (2021) [58] & TNmBC (82) & $\begin{array}{l}\text { Tissue samples } \\
\text { collected } \\
\text { at screening }\end{array}$ & PD-L1 & $22 \mathrm{C} 3$ & $\mathrm{IHC}$ & $\begin{array}{l}\text { PD-L1 IHC 22C3 pharmDx assay (Agilent, } \\
\text { Carpinteria, CA, USA) }\end{array}$ & $\begin{array}{l}\text { Combined } \\
\text { positive score }\end{array}$ & 0.01 & USA \\
\hline Voorwerk (2019) [59] & TNmBC (66) & at streermis & PD-L1 & $22 \mathrm{C} 3$ & IHC & $\begin{array}{l}\text { Dako IHC 22C3 pharmDx } \mathrm{Q}^{2} \\
\text { Solutions assay }\left(\mathrm{Q}^{2} \text { Solutions, }\right. \\
\text { West Lothian, UK) }\end{array}$ & TC and IC & NR & Netherland \\
\hline Yazdanpanah (2021) [60] & $\mathrm{mBC}(5)$ & FFPE/serum & $\begin{array}{l}\text { PD-L1/ } \\
\text { soluble } \\
\text { PD-L1 }\end{array}$ & E1L3N & IHC/ELISA & $\begin{array}{l}\text { E1L3N XP rabbit monoclonal antibody } \\
\text { (Cell Signaling Technology, Danvers, MA, } \\
\text { USA)/ELISA kit (R\&D, } \\
\text { Munich, Germany) }\end{array}$ & $\begin{array}{l}\text { TC/concentration of } \\
\text { soluble PD-L1 }\end{array}$ & $1 \% / 4.52 \mathrm{pg} / \mathrm{mL}$ & Iran \\
\hline Yuan (2019) [35] & mBC (47) & FFPE & PD-L1/PD-1 & NR & $\mathrm{IHC}$ & NR & $\begin{array}{l}\mathrm{TC} \text { and stromal } \\
\text { cell/IC }\end{array}$ & $1 \% / 1 \%$ & China \\
\hline
\end{tabular}

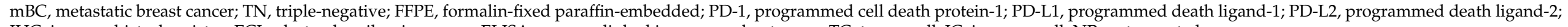
IHC, immunohistochemistry; ECL, electrochemiluminescence; ELISA, enzyme-linked immunosorbent assay; TC, tumor cell; IC, immune cell; NR, not reported. 


\subsection{Blood Sample}

Serum $(7.1 \%)$ and plasma (3.6\%) samples were used simultaneously with the tissue samples. Blood samples were obtained according to commercially available kits used in the studies. For serum samples, approximately $3.5 \mathrm{~mL}$ blood was drawn for soluble PD-L1 measurements according to instructions from the Meso Scale Discovery platform by Domchek et al. [42]. For plasma samples, lithium heparin BD blood collection vials were used and promptly centrifuged within $4 \mathrm{~h}$ to obtain fresh plasma. The plasma specimens were stored at $-80{ }^{\circ} \mathrm{C}$ until testing [47]. In general, the processing time and storage conditions of blood samples are critical for the stable and reliable measurement of target analytes [61]. Among the included studies, one study (3.6\%) used blood samples only for circulating epithelial tumor cells [55]. Ethylenediaminetetraacetic acid (EDTA) tubes were used to collect $7.5 \mathrm{~mL}$ of blood samples. These samples were also processed promptly within $48 \mathrm{~h}$ of collection to obtain reliable results.

\section{Targets}

\section{1. $P D-1 / P D-L 1$}

The PD-1 pathway is a major checkpoint for immune responses in the tumor microenvironment [62]. PD-1 (CD279) is an inhibitory co-receptor presented on the surface of T lymphocytes [63]. PD-L1 (also known as B7-H1; CD274) is mostly expressed on infiltrating immune cells [64]. The binding of PD-L1 to PD-1 leads to the inhibition of the $\mathrm{T}$ cell response, enabling self-tolerance and immune tolerance to prevent excessive immune reactions [65]. In malignant condition, cancer cells also present PD-L1 to inactivate and exhaust the T cell activation $[37,66]$. This mechanism involves immune escape or local suppression of the immune system (Figure 2). In BC, the expression of PD-1 is related to an aggressive phenotype including a high tumor grade and lack of ER expression [67]. The rate of PD-L1 expression by TC in triple-negative BC ranged from 19\% [68] to 59\% [69]. Both PD-1 and PD-L1 positive cells are observed more often in triple-negative BC than in other subtypes, resulting in worse outcomes in patients [69,70]. Blocking the PD-1/PD-L1 interaction through therapeutic monoclonal antibodies, known as immune checkpoint inhibitors, reduces immune suppression and generates the activity of tumor-specific T lymphocytes. Drugs that antagonize the PD-1 axis have demonstrated clinically effectiveness in patients with advanced tumors [33]. Therapeutic monoclonal antibodies such as pembrolizumab and nivolumab for PD-1, and atezolizumab, durvalumab, and avelumab for PD-L1 have been trialed and approved by the FDA [71]. Therefore, PD-1/PD-L1 expression by TC or infiltrating IC is under investigation as a predictive biomarker for response to blockade of the PD- 1 axis. Among the targets of PD- 1 axis, all included studies identified PD-L1 (100.0\%) (Figure 3A). Other targets simultaneously tested with PD-L1 were PD-1 (22.2\%), PD-L2 (33.3\%), and soluble PD-L1 (33.3\%) (Figure 3B). One study investigated all PD-L1, PD-1, and PD-L2 expression concurrently.

\section{2. $P D-L 2$}

The second ligand for PD-1 is PD-L2; however, its role in modifying immune responses is unclear and available information is limited. PD-L2 is usually presented at a lower level than PD-L1. However, the relative affinity of PD-L2 to PD-1 is 2 to 6-fold higher than that of PD-L1 because of direct interactions of PD-L2 with PD-1 [72]. Tryptophan (W110 ${ }_{\mathrm{PD}-\mathrm{L} 2}$ ) unique to PD-L2 contributes to different affinities. The W110PD-L2 plays the role of "elbow" and a C-D region functions as "latch", potentiating the affinity advantage of PD-L2 structurally [73,74]. In general, PD-L2 is expressed on immune cells including macrophages and dendritic cells [75]. Signaling pathways downstream of cytokine receptors and innate immune activators regulate PD-L2 expression. PD-L2 mainly plays a role in the induction phase of Th2-driven T-cell immune reactions. Tumor microenvironments usually deviate towards an ineffective Th2 type of immune condition, leading to cancer cells escaping from immune surveillance. Therefore, studies on the relevance of PD-2 in metastatic BC have 
been conducted [52,55,72]. PD-L2 accounted for $44.4 \%$ of the other targets simultaneously measured with PD-L1 (Figure 3B).

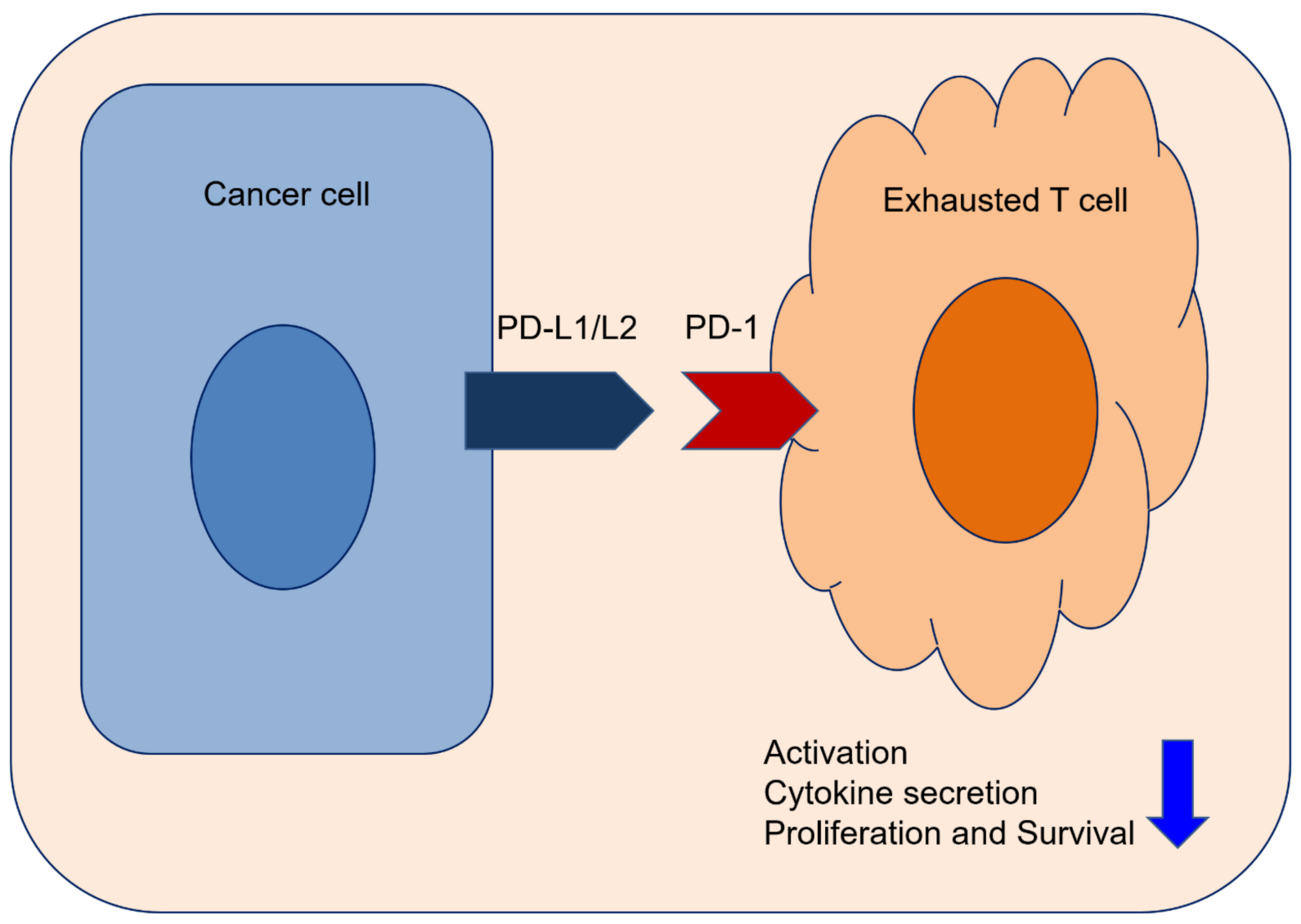

Figure 2. PD-1 axis exhausted T cell leading to immune escape.

\subsection{Soluble PD-L1}

Soluble PD-L1, which can attach to PD-1, is usually generated following proteolytic cleavage of membrane-bound PD-L1 by translation of alternatively spliced mRNA or matrix metalloproteinase [76]. Soluble PD-L1 has been reported to be a potential prognostic predictor in several cancers [47]. Soluble PD-L1 indicates an anti-immune response and cooperatively affects tumor progression. It is also associated with immune suppression through the regulatory function of T lymphocytes [77]. In addition to clinical significance, the expression of soluble costimulatory materials has been reported to be correlated with clinicopathological features such as lymph node and multiple organ metastasis. Therefore, soluble PD-L1 is a useful predictor in recurrent or metastatic BC before receiving the first line of therapy. High levels of soluble PD-L1 are related to shorter progression-free survival [78]. Regarding immunotherapy, therapeutic anti-PD-L1 might be absorbed by soluble PD-L1 before reaching TC, which alters the killing effect of BC cells on IC [60]. Meanwhile, a specific anti-PD-L1 antibody agent might suppress the expression of soluble PD-L1 and remove its blocking effect on the PD-1 negative signaling pathway, leading to improving T cell viability and enhancing the killing of BC cells [47]. There have been several studies investigating soluble PD-L1 because abnormalities in this factor are involved in early and long-term immune modulation. The soluble form of PD-L1 consists of $33.3 \%$ of the other targets assessed with PD-L1 (Figure 3B). 
A

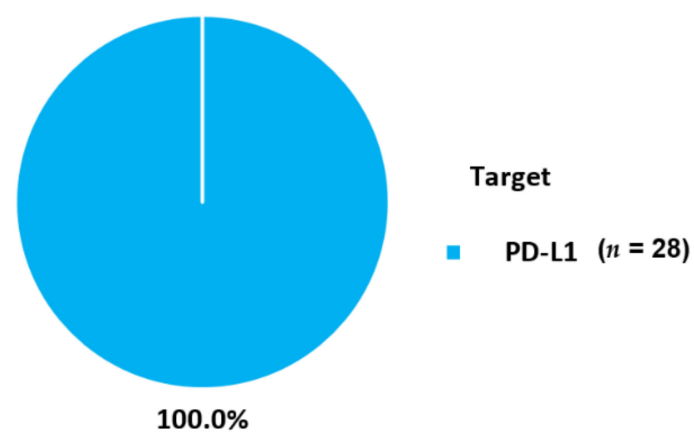

B

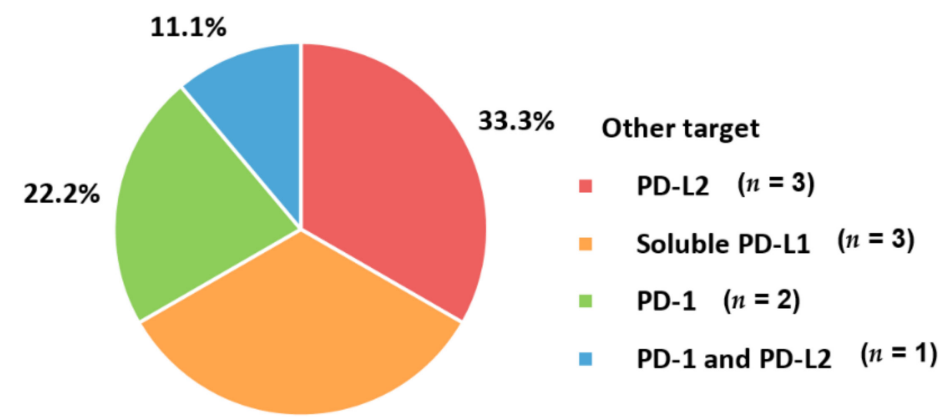

$33.3 \%$

\section{C}

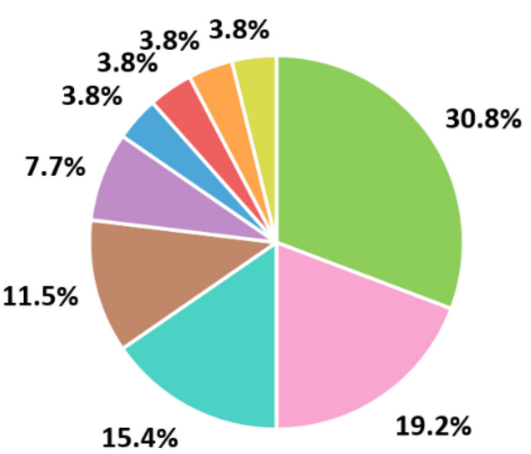

Anti-PD-L1 antibody clone

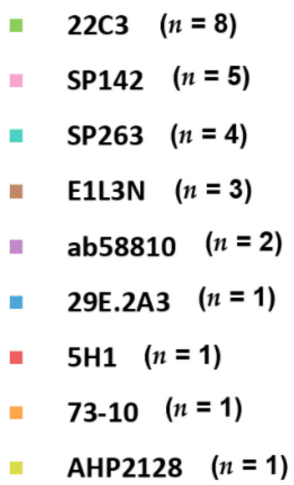

Figure 3. Targets of PD-1 axis and antibody clones for PD-L1. (A) Pie charts showing the target of PD-L1; (B) pie charts presenting other targets concurrently used with PD-L1; and (C) pie charts showing the antibody clones of PD-L1. PD-1, programmed cell death protein-1; PD-L1, programmed death ligand-1; PD-L2, programmed death ligand-2. 


\section{Anti-PD-L1 Antibody Clone}

A total of nine types of anti-PD-L1 antibody clones were identified in studies on PD-L1 expression in metastatic BC (Figure 3C). Among clones occupying more than $10 \%$, PD-L1 22C3 was used most commonly (30.8\%), followed by SP142 (19.2\%), SP263 (15.4\%), and E1L3N (11.5\%). The binding epitope of the $22 \mathrm{C} 3$ clone is a discontinuous segment of the extracellular domain [79]. The binding site of 22C 3 contains $\mathrm{N}$-linked glycosylation, which may influence the binding efficacy of antibodies and is related to variability in antigen retrieval. Meanwhile, SP142, SP263, and E1L3N bind to the C-terminal cytoplasmic domain [25]. Cytoplasmic staining may show a punctate or granular pattern [80]. Studies comparing PD-L1 assays in triple-negative BC demonstrated discrepancies among assays using 22C3, SP142, and SP263 clones [53,81]. The results of the 22C3, SP263, and E1L3N assays were broadly comparable, whereas SP142 showed lower PD-L1 expression on TC $[53,81,82]$. The assays with 22C 3 and SP263, which have lower sensitivity for IC, mainly stained macrophages and dendritic cells.

Meanwhile, SP142 stained IC, such as some CD68 positive lymphocyte-like cells $[83,84]$. IC staining was easily identified using the SP142 assay because of the lower prevalence of TC staining. Therefore, SP142 showed higher inter-reader agreement for studies with PD-L1 IC $>1 \%[82,85]$. The clinical trial (IMpassion 130) [23] evidencing the FDA approval of the VENTANA platform as a companion test for atezolizumab in triple-negative BC, adopted SP142 clone available only in VENTANA Medical Systems. The scoring method applied to this study was IC, which is unique to SP142 clone. Regulatory agencies have approved only the SP142 assay as a complementary diagnostic test for the administration of atezolizumab in countries such as the United States, Japan, Sweden, Peru, and Argentina. In particular, only the SP142 assay is covered by the health system of Japan because regulatory agencies have approved it as a companion diagnostic test for triple-negative BC. On the other hand, the European Union (EU), China, and Brazil permit validation of the PD-L1 assay. Drugs are not mandatorily correlated with companion assays in the EU. The lower prevalence of PD-L1 positivity determined by the SP142 clone could potentially reveal fewer patients selected for immunotherapy. Meanwhile, the use of 22C3 or SP263 could lead to greater patient eligibility. However, there are still concerns about drug toxicity and financial costs without clinical benefit because of false-positive results.

In the most commonly used $22 \mathrm{C} 3$ clones in metastatic $\mathrm{BC}$, pembrolizumab for $\mathrm{PD}$ L1 (22C3)-selected metastatic triple-negative BC patients might be approved based on the conclusions of an expert round-table discussion [31]. Laboratories performing PD-L1 testing for lung cancer have already used other assays, most frequently 22C3 and SP263 assays $[86,87]$. Some laboratories could have difficulty developing and validating the SP142 assay. Further, commercial diagnostic assays for $22 \mathrm{C} 3$ are available and can be performed on different platforms. In addition, PD-L1 testing could be performed on other clones, such as SP263 and E1L3N, if analytically validated and permitted by regulatory agencies. Based on our data, 22C3 assays were frequently performed on a platform from Agilent and Merck \& Co. of the United States and Q2 solutions of the UK. Meanwhile, assays for SP142 and SP263 were performed on a platform from Ventana Medical Systems. For E1L3N, clones from cell signaling were frequently used to detect PD-L1 expression (Table 1).

\section{Applied Methods}

\subsection{Immunohistochemistry (IHC)}

IHC is the most commonly used technique for the detection of the PD- 1 axis in patients with metastatic BC (Figure 4A). The antibodies selectively binding to target antigens such as PD-1, PD-L1, and PD-L2 is essential for proper protein identification from fresh and appropriately processed tissue [88]. Antibodies conjugated to an enzyme enable the visualization of an antibody-antigen complex [89]. Commercially available PD-L1 assays, adopting specific antibody clones, are commonly utilized in some studies for metastatic BC. Each assay using a specific score and cut-off has been applied to these studies targeting specific immune checkpoint inhibitors. Furthermore, commercial assays have been validated using 
specific platforms. Providing specific information about the adopted assay, antibody clones, related platforms, and validated in-house protocols used in clinical laboratories is necessary, especially if the applied immune checkpoint inhibitors are associated with companion diagnostic tests for the PD-1 axis. FDA approval of some immunotherapies is indeed associated with specific companion assays [23,71]. On the other hand, many laboratories in European countries have established laboratory-developed tests according to current practices in the European Union (Table 1). Therefore, the manufacturer's recommendations, established in-house protocols considering the regional guidelines and accredited institutions are important for testing the IHC of PD-L1 [37]. For the most commonly used 22C 3 clone, several IHC detection systems such as Link 48 autostainer and EnVision Flex from Agilent and OptiView DAB IHC detection kit from Ventana Medical System have been applied $[25,37,58]$. Meanwhile, the SP142 clone has been mostly associated with the OptiView DAB IHC detection kit from Ventana Medical System [40]. In terms of SP263, Ventana BenchMark Ultra autostainer using the OptiVew DAB IHC detection kit from Ventana Medical System was also commonly used [49,57]. For the E1L3N clone, Leica Bond-Max Autostainer (Leica Biosystems) was used for PD-L1 IHC [46]. The advantage of IHC is its ability to reveal the exact location of a targeting antigen within the tissue. Furthermore, the procedure requires only a small amount of tissue and is relatively simple and inexpensive. However, the results should be interpreted cautiously as this method is semi-quantitative and various scoring methods and cutoffs are applied to the results [90]. Harmonization studies comparing different staining and counting methods are needed, particularly for metastatic BC.

\subsection{Enzyme-Linked Immunosorbent Assay (ELISA)}

Studies that use plasma or serum samples for soluble PD-L1 detection have adopted ELISA (Figure 4B). In these immunoassays, enzymes are conjugated to secondary antibodies, which bind to the soluble PD-L1 antigen-antibody complex. The conjugated enzyme catalyzes the production of a colored end product after the addition of appropriate substrate and incubation. The catalyzed products can be visualized and quantified [91]. Distinguishing specific soluble PD-L1 antigens from nonspecific complexes is required for most commercial enzyme immunoassay systems such as ELISA. Regarding sandwich ELISA, which is commonly utilized to identify soluble PD-L1, plasma or serum specimens are firstly added to a well coated with an immobilized antigen-specific antibody. If the soluble PD-L1 is present, it will attach to the antibody. After washing out, a secondary antibody targeting the soluble PD-L1 is added. An enzyme conjugated to this secondary antibody directly or the third conjugated antibody to the Fc region of the second antibody can be catalyzed to produce the color reaction when the substrate is added. The amount of color is proportional to the amount of targeted soluble PD-L1 in the specimen. When used to identify soluble PD-L1, the targeted materials of soluble PD-L1 are "sandwiched" between two monoclonal antibodies. Absorbance is determined at a specific wavelength using a spectrophotometer. The concentration is calculated through a standard curve plotted from the known concentrations of the ligand. The kits from USCN Life Science and R\&D system used for the determination of soluble PD-L1 in metastatic BC studies were sandwich ELISA assays $[47,60]$. Due to the easy accessibility and non-invasiveness of blood samples, ELISA-based tests have been applied to the measurement of soluble PD-L1. In addition, providing quantitative values and relatively rapid turnaround times with shorter hands-on time makes this technique available in several laboratories. Further studies are needed to validate these blood sample-based methods. Although IHC of tissue is widely used as a reference, these assays might be more popular because of the advantages of detecting soluble targets. 
A

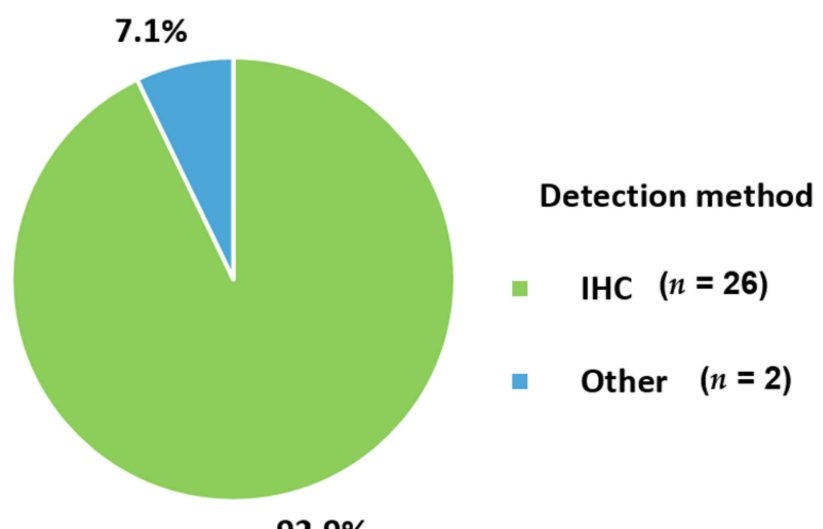

B

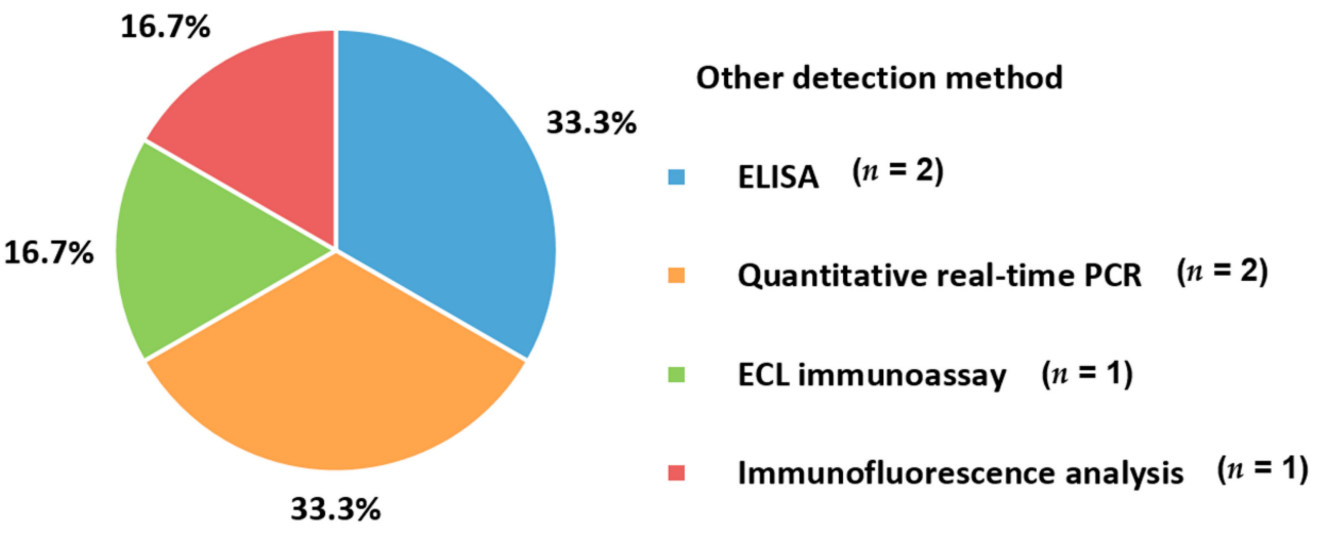

Figure 4. Applied techniques to detecting the PD-1 axis. (A) Pie chart representing the detection method; (B) pie charts showing other detection methods for the PD-1 axis. PD-1, programmed cell death protein-1; IHC, immunohistochemistry; ECL, electrochemiluminescent immunoassay; ELISA, enzyme-linked immunosorbent assay.

\subsection{Electrochemiluminescent Immunoassay (ECL)}

One study on soluble PD-L1 in metastatic BC used an ECL. This technique utilizes electrochemical compounds as labels to generate light from an oxidation-reduction reaction. $\mathrm{Ru}(\mathrm{bpy})_{3}{ }^{2+}$ regenerated with tripropylamine is used for ECL for superior performance. It can be a useful imaging tool because of the inherent luminosity [91,92]. The generated photons are identified using photomultiplier tubes, silicon photodiodes, or gold-coated fiber-optic sensors. Its high sensitivity, low background, and easily controlled characteristics make this technique preferable $[93,94]$. In addition, the variation in the electrode potential improved the selectivity of this method [95]. Regarding soluble PD-L1, the mesoscale discovery platform adopted the ECL technique employing biotinylated antiPD-L1 capture antibody clone 2.7 A4 [42]. During incubation, soluble PD-L1 in the serum sample bound to anti-PD-L1-specific antibodies immobilized on a streptavidin-coated 96-well plate. After the unbound substances were removed, the primary antibody was identified by the addition of a ruthenium-labeled secondary antibody. Chemiluminescent emission after the application of voltage to the electrode was detected using a photomultiplier tube. The values were determined using a calibration curve. The subject-based limit of detection was $67.1 \mathrm{pg} / \mathrm{mL}$ and the quantitation range was $15.6-1000 \mathrm{pg} / \mathrm{mL}$. 


\subsection{Fluorescence Immunoassay}

Fluorescence immunoassays generally use fluorescently labeled antibodies [96]. When a fluorophore is excited, light at a specific wavelength is generated. A fluorometer provides the excitation light source and the immunofluorescence microscopy or photomultiplier tube detects the emission fluorescence. The selection of substrates without substances emitting fluorescent light is important for improving the sensitivity of this assay [97]. In addition, the correct absorption wavelength is necessary to excite the fluorophore tag attached to the antibody and to identify the released fluorescence. Schott et al. [55] adopted a fluorescence immunoassay for circulating epithelial tumor cells to detect PD-L1 and PD-L2. Cells with green, red, and blue surface staining and well-preserved nuclei were visualized. The results for PD-L1 and PD-L2 were calculated as a percentage of the total number of circulating tumor cells.

\subsection{Quantitative Real-Time PCR}

One study used quantitative real-time PCR to investigate the immunogenomic dynamics of metastatic BC [55]. The expression levels of immune-related genes in the biopsied samples were measured by quantitative real-time PCR. Another study on the methylation of PD-L1 was also performed using this technique [46]. Real-time PCR is commonly utilized for the analysis of gene expression and quantification [98]. Nucleic acid extraction and purification are the basic procedures for this technique. Bisulfite conversion of DNA was performed for methylation analysis. The target materials were amplified using PCR. The PCR thermal cycling program is composed of denaturation, annealing, and elongation. Quantification can be conducted using real-time PCR. The simultaneously performing reverse transcription PCR and real-time PCR enables combined nucleic acid amplification and detection in a single step [99]. Real-time PCR assays utilizing target-specific probes to detect amplified products is generally adopted in clinical laboratories. TaqMan probes are commonly used as fluorescent probes for real-time PCR. The probes hybridize to the target sequences and cleave the fluorescent probe during the PCR amplification step. The decoupling of the quencher material and fluorescent probe improved the fluorescence intensity [100]. The disadvantages of TaqMan probes are that they are time-consuming, expensive, and require separate probes for each RNA target. In addition, the spectral overlap of fluorophores should be cared about, especially for fluorescent PCR assays. Confirming the specificity of probe hybridization with caution when considering its relative convenience and usefulness. These TaqMan probes were used to detect the PD-L1 and $P D$ - 2 genes in metastatic BC. Although quantitative real-time PCR is highly sensitive, RNA degradation, contamination, false-positive results due to non-specific amplification, and false-negative results due to lower levels of gene expression should be considered.

\section{Scoring Methods}

In the evaluation of PD-L1 expression to select patients for immunotherapy, various cell types and different cutoffs have been applied to studies of metastatic BC (Figure 5). The combination method, including both TC and IC, consisted of $52 \%$ of all included scoring methods. The following methods were used to count the TC (36\%) and IC (12\%). PD-L1 expression by IHC was evaluated semi-quantitatively by a pathologist. Because of the subjective aspects of interpretation and poor reproducibility, analysis by at least 8-10 pathologists was recommended for reproducibility of PD-L1 expression according to a summary of an expert round-table discussion [31]. Moreover, training in PD-L1 assessment for pathologists annual internal and external quality assurance is recommended [25,101]. In general, TC is counted as PD-L1 positive if membranous staining is present. If there is cytoplasmic staining without membranous staining, the TC is considered PD-L1-negative. In contrast, either granular cytoplasmic or incomplete membranous staining can be designated as a positive count for IC $[66,80,85]$. IC, including granulocytes, lymphocytes, dendritic cells, and macrophages, can be found in clusters or dispersed single cells. The presence and distribution of ICs in the tumor area should be recorded. At least 50-100 TC 
and associated stroma should be presented, and the whole tumor area without necrotic areas must be assessed. Staining artifacts, necrosis, or intravascular IC were excluded from the assessment. The scoring methods were varied and classified into TC, IC, and the combination of TC and IC. First, TC was composed of tumor cell and tumor proportion scores. The tumor cell score is defined as the percentage of the area composed of PD-L1 positive TCs in the entire tumor area [102]. Meanwhile, the tumor proportion score defines the ratio of PD-L1 positive TC, relative to all TCs, multiplied by $100 \%$ [103]. Second, for immune cell score, all IC located in the intra-TC region or peri-tumor stromal rim were considered when calculating the score. The percentage of the area occupied by all PD-L1 positive IC relative to the whole tumor area, including TC and associated, was counted. Lastly, the combined positive score involves both TC and IC located in the TC or the narrow rim around the TC. The number of PD-L1-positive TCs and ICs was counted, relative to the number of all vital TCs, and then multiplied by 100 [102,104]. These scoring methods were associated with the adopted clones. The SP142 assay usually counts the IC. Meanwhile, 22C3, SP263, and E1L3N determine TC and the combination of TC and IC, as well as IC only. Therefore, the proportions of combination and TC were higher than those of IC in the included studies (Figure 5). Regarding the cutoffs, 80\% of the studies (20 out of 25 studies utilizing IHC with reported cutoff values) adopted a cutoff value of $1 \%$ (Table 1 ). In the TC scoring method, two studies applied a 5\% cutoff $[41,46]$. For IC and combination scoring methods, a $10 \%$ cutoff was applied to the IC of three studies [36,52,57]. Because of this heterogeneity, reports on PD-L1 detection should contain information about the antibody clone, the applied scoring method with cutoff, and the relevant therapeutic setting of the respective tumor and approved drug. Additionally, the staining assay and platform used can also be described $[25,102]$.

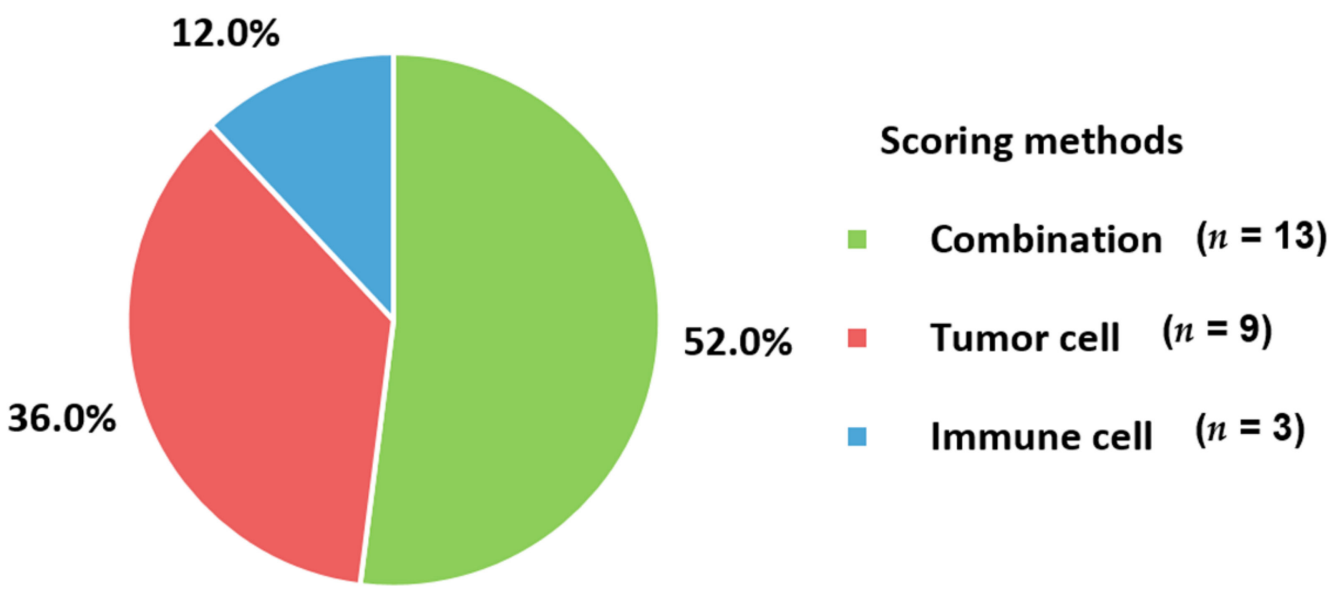

Figure 5. Applied scoring methods to identifying PD-1 axis. PD-1, programmed cell death protein-1.

\section{Trends in Applied Assays for Metastatic BC}

The changes in samples for identifying the PD-1 axis in metastatic BC according to the period of examination are presented in Figure 6. The use of blood samples $(20.0 \%)$ in 20192021 was higher than that in 2016-2018 (7.7\%). Measurement of soluble type of PD-L1 with samples having easier accessibility and non-invasiveness could influence changes in user preferences. There were no changes in the targeting substances for PD-L1 between 20162018 and 2019-2021 because all included studies measured PD-L1 expression (Figure 7A). PD-L1 would be assayed essentially as a companion test when immune checkpoint inhibitors are prescribed. For targets other than PD-L1, PD-L2 was commonly determined in 2016-2018; it is no longer used in 2019-2021. PD-L2 is expressed in only a minority of patients compared to PD-L1 [55]. Furthermore, the role of PD-L2 in modulating immune responses is less obvious, which leads to a lack of targeted drugs [72] and a decreased number of tests in 2019-2021. PD-L2 would be mainly assayed for research use only rather 
than clinical practice. In contrast, PD-1 could be tested when immune checkpoint inhibitors targeting PD-1, such as pembrolizumab and nivolumab, are administered to BC patients. The advent of kits for soluble PD-L1 led to the differences in the targets between 2016-2018 and 2019-2021 (Figure 7B). The number of anti-PD-L1 antibody clones decreased from 7 to 5 between 2016-2018 and 2019-2021 (Figure 7C). Commonly used clones, such as 22C3 and SP142, were consistently used in 2019-2021 and 2016-2018. The proportions of 22C3 and SP142 in 2019-2021 increased because of the use of commercialized PD-L1 kits rather than in-house assays. In particular, the wider use of the SP142 clone is related to clinical trials such as IMpassion130 trial [105] and led to regulatory agencies mandating specific companion diagnostic tests. In addition, the use of SP263 associated with durvalumab and E1L3N was also reflected in the clones from 2019-2021. For the detection method, IHC became an essential assay in 2019-2021 (Figure 8A). There have been no studies without IHC in recent times. Additionally, for the changes in other detection methods, ELISA and ECL, which are capable of quantitative measurement of soluble PD-L1, were introduced and became the main techniques (Figure 8B). The proportion of combination scoring increased from $45.5 \%$ in 2016-2018 to 57.1\% in 2019-2019 (Figure 9). These changes might have occurred because of the increased proportion of $22 \mathrm{C} 3$ clones concurrently counting IC and TC. 


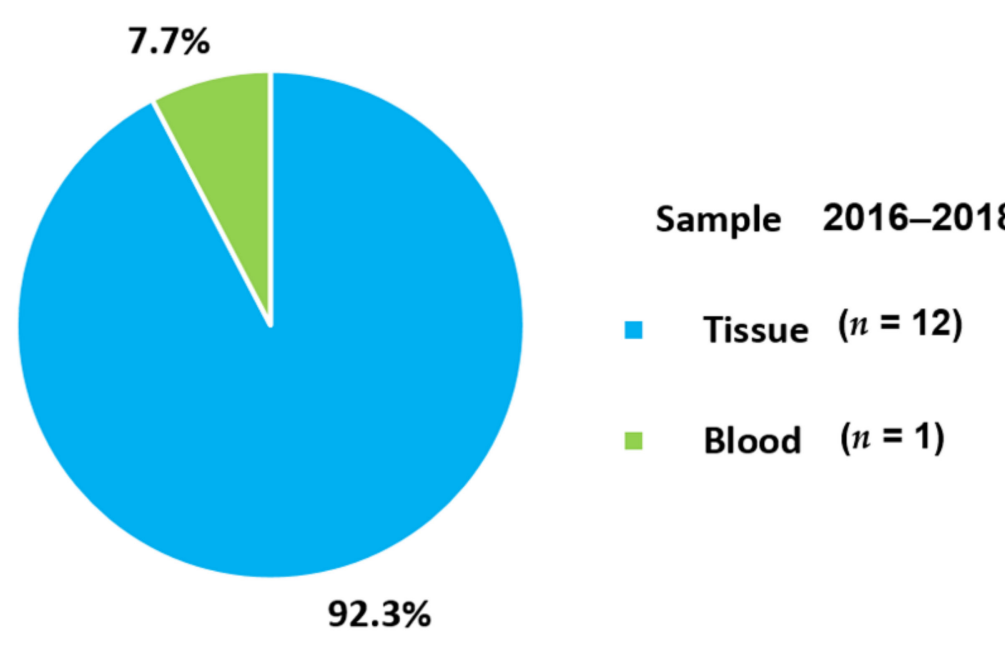

Figure 6. Changes in the used sample types according to the epoch. 
A

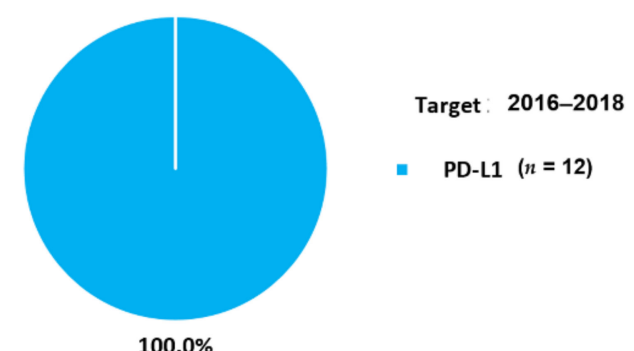

B

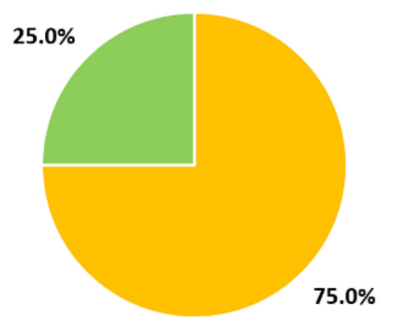

Other target 2016-2018

PD-L2 $(n=3)$

- PD-1 and PD-L2 $(n=1)$

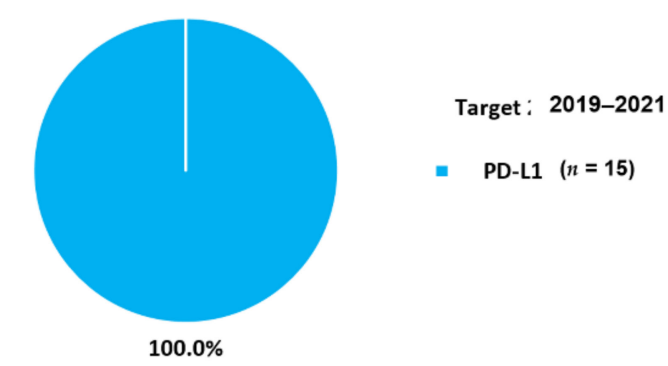

C

Anti-PD-L1 antibody

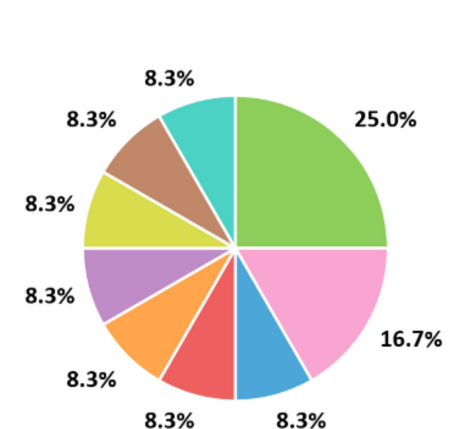

22C3 $(n=3)$

SP142 $(n=2)$

- 29E.2A3 $(n=1)$

- $5 \mathrm{H} 1 \quad(n=1)$

73-10 $(n=1)$

- ab58810 (n=1)

- AHP2128 $(n=1)$

- E1L3N $(n=1)$
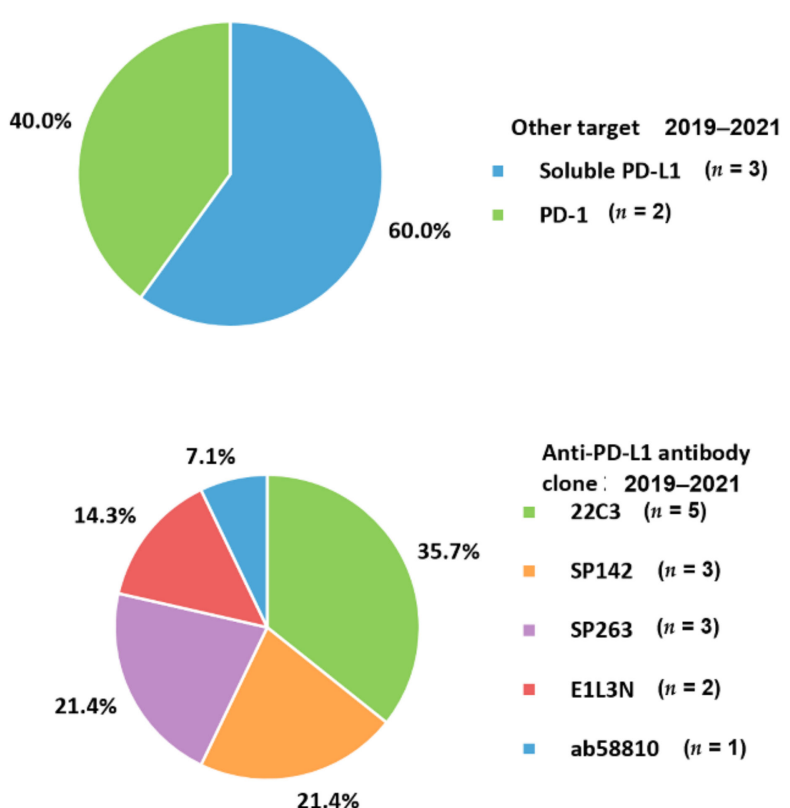

- SP263 $(n=1)$

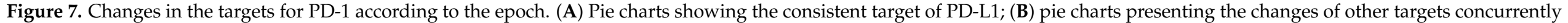

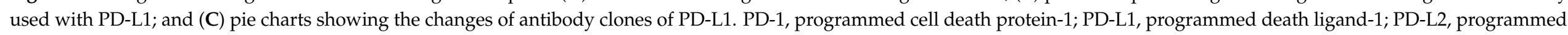
death ligand-2. 
A

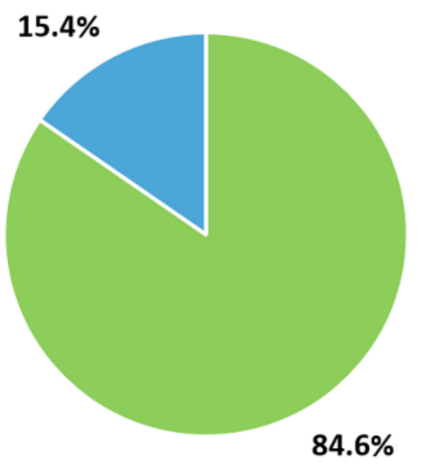

\section{Detection method 2016-2018}

IIHC $(n=11)$

- Other $(n=2)$

$4.6 \%$

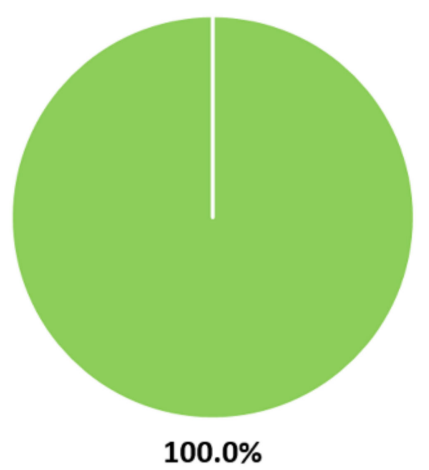

Detection method 2019-2021

B
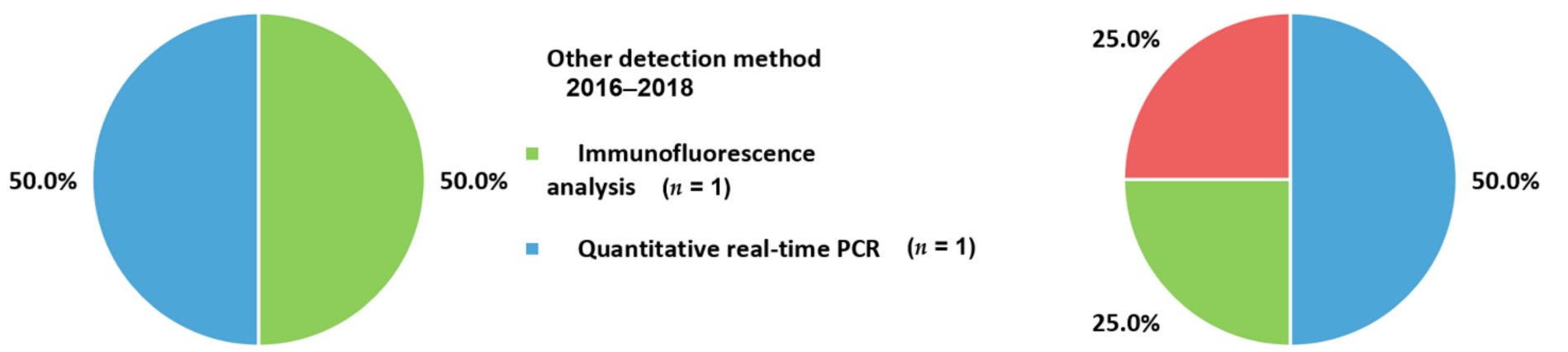

Other detection method 2019-2021

- ELISA $(n=2)$

- ECL immunoassay $(n=1)$

- Quantitative real-time PCR $\quad(n=1)$

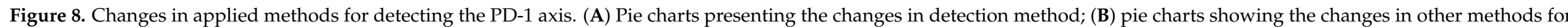
detecting the PD-1 axis. PD-1, programmed cell death protein-1; IHC, immunohistochemistry; ECL, electrochemiluminescence; ELISA, enzyme-linked immunosorbent assay. 


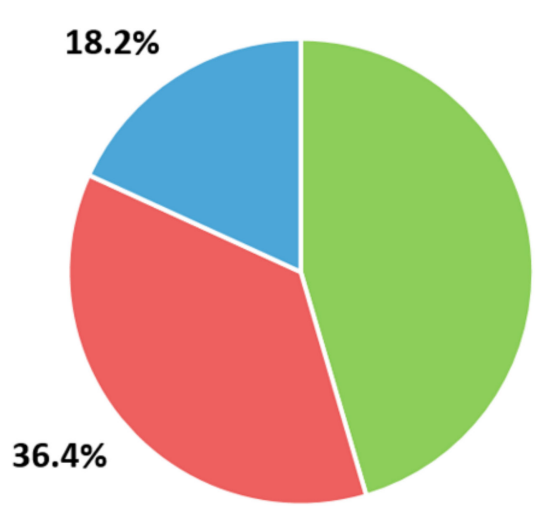

Scoring methods 2016-2018

$45.5 \%$

Combination $(n=5)$

- Tumor cell ( $n=4)$

Immune cell $\quad(n=2)$

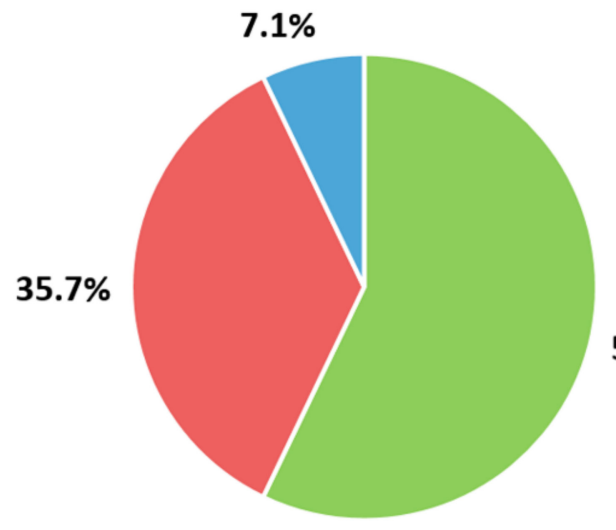

Tumor cell $(n=5)$

Immune cell $(n=1)$

Figure 9. Changes in scoring methods for PD-1 axis. PD-1, programmed cell death protein-1. 


\section{Future Perspectives}

Detection of PD-L1 using IHC has been widely used for selecting the best candidates for immunotherapy $[71,106]$. The procedure needs to be effective and reproducible through further concordance studies, standardized protocols, and guidelines. In addition, studies are needed to identify biomarkers with strong predictive values. Soluble PD-L1 is beneficial for TC to resist the killing and elimination of lymphocytes in the tumor microenvironment. Although soluble PD-L1 has been recognized as a naturally occurring modulator of PD-1 signaling pathways, its biological activity remains poorly understood. Further studies are needed to better understand the implications of soluble PD-L1 levels on immunotherapy efficacy in metastatic BC. Moreover, diverse methods have been utilized for the enrichment and detection of circulating tumor cells $[107,108]$. The developed techniques demonstrated high sensitivity and facilitated the quantification of these cells $[109,110]$. However, analyses of images can be subjective, and therefore, data should be interpreted with caution because of the high background fluorescence related to this methodology. Sophisticated techniques for detecting the PD-1 axis are currently being developed for future use. The rapid and accurate detection based on the advent of newly developed techniques will substantially benefit patients receiving immunotherapy. Furthermore, the genetic profiling of the PD-1 axis using molecular tools such as microarrays and next-generation sequencing might increase the accuracy of predicting responses to immunotherapies. Analytical and clinical validation should be conducted before using new techniques in clinical laboratories. Furthermore, targeting only the PD- 1 axis alone cannot explain the complete restoration of $\mathrm{T}$ cell function [111]. Therefore, the identification of other substances involved in T cell dysfunction is also required. Tumor infiltrating lymphocytes (TILs), a prognostic biomarker in various types of cancers, has been reported to be related to the prognosis of triple-negative BC $[3,112,113]$. Recently, CD73 expressed on cancer and immune cells has been investigated as a molecular immunosuppressive factor in triple-negative BC [112]. CD73 can increase extracellular adenosine by converting adenosine monophosphate to adenosine, which activates high affinity A2A and A2B adenosine receptors leading to immune suppression [113]. Therefore, reports have associated CD73 overexpression with anthracycline resistance [114] and worse prognosis in triple-negative BC [112,115]. Although PD-1 axis is one of the main mechanisms for immune escaping, the prognostic implications of PD-L1 are limited $[116,117]$. The combination of these other markers with PD-1 axis could be proposed as a useful predictive tool [115]. In addition, further studies investigating the effect of anti-CD73 antibody therapy on reprogramming the tumor microenvironment would contribute to better outcomes of metastatic BC.

\section{Conclusions}

In conclusion, we reviewed the applied laboratory techniques for detecting PD-1, PD-L1, PD-L2, and soluble PD-L1, which are important markers for selecting metastatic BC patients for targeted immunotherapy. In laboratories, the main method used for PD-1 axis is identifying expression in IHC with tissue samples. The most commonly used anti-PD-L1 antibody clones are 22C3, SP142, SP263, and E1L3N. Assays targeting soluble PD-L1, such as ELISA and ECL, have been developed and have been widely utilized. Easy accessibility and non-invasiveness due to the use of blood samples, providing quantitative values, and relatively rapid turnaround times with shorter hands-on time make these techniques preferable in several laboratories. For the scoring methods, the combination of TC and IC, rather than each cell alone, became more popular in correlation with the increased use of 22C3. To use these assays, it is important to have a comprehensive understanding of the associated principles, advantages, disadvantages, and precautions for accurate data interpretation. In particular, providing information about utilized antibody clones, platforms, scoring methods, and related companion drugs is recommended for reporting PD-L1 expression. 
Author Contributions: Conceptualization, N.L. and S.J.; methodology, K.J.; software, N.L.; validation, M.-J.P. and W.S.; formal analysis, N.L. and S.J.; investigation, N.L.; resources, K.J. and S.J.; data curation, W.S. and S.J.; writing —original draft preparation, N.L.; writing-review and editing, M.-J.P. and W.S.; visualization, K.J.; supervision, M.-J.P. and W.S.; project administration, S.J.; funding acquisition, S.J. All authors have read and agreed to the published version of the manuscript.

Funding: This research was funded by National Research Foundation of Korea (NRF) grant, grant number (NRF-2017R1C1B2004597). The APC was funded by NRF.

Acknowledgments: The authors would like to thank Hyun Jung Kim (Korea University College of Medicine) and the Biomedical Research Institute (Pusan National University Hospital) for providing technical support and statistical consultation.

Conflicts of Interest: The authors declare no conflict of interest. The funders had no role in the design of the study; in the collection, analyses, or interpretation of data; in the writing of the manuscript, or in the decision to publish the results.

\section{References}

1. Ferlay, J.; Colombet, M.; Soerjomataram, I.; Parkin, D.M.; Pineros, M.; Znaor, A.; Bray, F. Cancer statistics for the year 2020: An overview. Int. J. Cancer 2021, 149, 778-789. [CrossRef]

2. Siegel, R.L.; Miller, K.D.; Jemal, A. Cancer statistics, 2020. CA Cancer J. Clin. 2020, 70, 7-30. [CrossRef] [PubMed]

3. Global Cancer Observatory: Cancer Today. Available online: https://gco.iarc.fr/today/online-analysis-table (accessed on 11 June 2021).

4. Huang, Z.; Wen, W.; Zheng, Y.; Gao, Y.T.; Wu, C.; Bao, P.; Wang, C.; Gu, K.; Peng, P.; Gong, Y.; et al. Breast cancer incidence and mortality: Trends over 40 years among women in Shanghai, China. Ann. Oncol. 2016, 27, 1129-1134. [CrossRef] [PubMed]

5. Sung, H.; Ferlay, J.; Siegel, R.L.; Laversanne, M.; Soerjomataram, I.; Jemal, A.; Bray, F. Global Cancer Statistics 2020: GLOBOCAN Estimates of Incidence and Mortality Worldwide for 36 Cancers in 185 Countries. CA Cancer J. Clin. 2021, 71, 209-249. [CrossRef] [PubMed]

6. Joko-Fru, W.Y.; Jedy-Agba, E.; Korir, A.; Ogunbiyi, O.; Dzamalala, C.P.; Chokunonga, E.; Wabinga, H.; Manraj, S.; Finesse, A.; Somdyala, N.; et al. The evolving epidemic of breast cancer in sub-Saharan Africa: Results from the African Cancer Registry Network. Int. J. Cancer 2020, 147, 2131-2141. [CrossRef] [PubMed]

7. Bray, F.; McCarron, P.; Parkin, D.M. The changing global patterns of female breast cancer incidence and mortality. Breast Cancer Res. 2004, 6, 229-239. [CrossRef]

8. Heer, E.; Harper, A.; Escandor, N.; Sung, H.; McCormack, V.; Fidler-Benaoudia, M.M. Global burden and trends in premenopausal and postmenopausal breast cancer: A population-based study. Lancet Glob. Health 2020, 8, e1027-e1037. [CrossRef]

9. Romieu, I.; Biessy, C.; Carayol, M.; His, M.; Torres-Mejia, G.; Angeles-Llerenas, A.; Sanchez, G.I.; Jaramillo, R.; Navarro, E.; Porras, C.; et al. Reproductive factors and molecular subtypes of breast cancer among premenopausal women in Latin America: The PRECAMA study. Sci. Rep. 2018, 8, 13109. [CrossRef]

10. Althuis, M.D.; Dozier, J.M.; Anderson, W.F.; Devesa, S.S.; Brinton, L.A. Global trends in breast cancer incidence and mortality 1973-1997. Int. J. Epidemiol. 2005, 34, 405-412. [CrossRef] [PubMed]

11. Malvezzi, M.; Carioli, G.; Bertuccio, P.; Boffetta, P.; Levi, F.; La Vecchia, C.; Negri, E. European cancer mortality predictions for the year 2019 with focus on breast cancer. Ann. Oncol. 2019, 30, 781-787. [CrossRef]

12. Kennecke, H.; Yerushalmi, R.; Woods, R.; Cheang, M.C.; Voduc, D.; Speers, C.H.; Nielsen, T.O.; Gelmon, K. Metastatic behavior of breast cancer subtypes. J. Clin. Oncol. 2010, 28, 3271-3277. [CrossRef]

13. DeSantis, C.E.; Ma, J.; Gaudet, M.M.; Newman, L.A.; Miller, K.D.; Goding Sauer, A.; Jemal, A.; Siegel, R.L. Breast cancer statistics, 2019. CA Cancer J. Clin. 2019, 69, 438-451. [CrossRef] [PubMed]

14. Mariotto, A.B.; Etzioni, R.; Hurlbert, M.; Penberthy, L.; Mayer, M. Estimation of the Number of Women Living with Metastatic Breast Cancer in the United States. Cancer Epidemiol. Biomark. Prev. 2017, 26, 809-815. [CrossRef]

15. Yersal, O.; Barutca, S. Biological subtypes of breast cancer: Prognostic and therapeutic implications. World J. Clin. Oncol. 2014, 5, 412-424. [CrossRef] [PubMed]

16. Caswell-Jin, J.L.; Plevritis, S.K.; Tian, L.; Cadham, C.J.; Xu, C.; Stout, N.K.; Sledge, G.W.; Mandelblatt, J.S.; Kurian, A.W. Change in Survival in Metastatic Breast Cancer with Treatment Advances: Meta-Analysis and Systematic Review. JNCI Cancer Spectr. 2018, 2, pky062. [CrossRef] [PubMed]

17. Vondeling, G.T.; Menezes, G.L.; Dvortsin, E.P.; Jansman, F.G.A.; Konings, I.R.; Postma, M.J.; Rozenbaum, M.H. Burden of early, advanced and metastatic breast cancer in The Netherlands. BMC Cancer 2018, 18, 262. [CrossRef] [PubMed]

18. Ray, M.; Polite, B.N. Triple-negative breast cancers: A view from 10,000 feet. Cancer J. 2010, 16, 17-22. [CrossRef] [PubMed]

19. Seal, M.D.; Chia, S.K. What is the difference between triple-negative and basal breast cancers? Cancer J. 2010, 16, 12-16. [CrossRef]

20. Gradishar, W.J.; Anderson, B.O.; Abraham, J.; Aft, R.; Agnese, D.; Allison, K.H.; Blair, S.L.; Burstein, H.J.; Dang, C.; Elias, A.D.; et al. Breast Cancer, Version 3.2020, NCCN Clinical Practice Guidelines in Oncology. J. Natl. Compr. Cancer Netw. 2020, 18, 452-478. [CrossRef] [PubMed] 
21. Cardoso, F.; Paluch-Shimon, S.; Senkus, E.; Curigliano, G.; Aapro, M.S.; Andre, F.; Barrios, C.H.; Bergh, J.; Bhattacharyya, G.S.; Biganzoli, L.; et al. 5th ESO-ESMO international consensus guidelines for advanced breast cancer (ABC 5). Ann. Oncol. 2020, 31, 1623-1649. [CrossRef]

22. Li, C.H.; Karantza, V.; Aktan, G.; Lala, M. Current treatment landscape for patients with locally recurrent inoperable or metastatic triple-negative breast cancer: A systematic literature review. Breast Cancer Res. 2019, 21, 143. [CrossRef]

23. Schmid, P.; Adams, S.; Rugo, H.S.; Schneeweiss, A.; Barrios, C.H.; Iwata, H.; Dieras, V.; Hegg, R.; Im, S.A.; Shaw Wright, G.; et al. Atezolizumab and Nab-Paclitaxel in Advanced Triple-Negative Breast Cancer. N. Engl. J. Med. 2018, 379, 2108-2121. [CrossRef] [PubMed]

24. Gong, J.; Chehrazi-Raffle, A.; Reddi, S.; Salgia, R. Development of PD-1 and PD-L1 inhibitors as a form of cancer immunotherapy: A comprehensive review of registration trials and future considerations. J. Immunother. Cancer 2018, 6, 8. [CrossRef] [PubMed]

25. Gonzalez-Ericsson, P.I.; Stovgaard, E.S.; Sua, L.F.; Reisenbichler, E.; Kos, Z.; Carter, J.M.; Michiels, S.; Le Quesne, J.; Nielsen, T.O.; Laenkholm, A.V.; et al. The path to a better biomarker: Application of a risk management framework for the implementation of PD-L1 and TILs as immuno-oncology biomarkers in breast cancer clinical trials and daily practice. J. Pathol. 2020, 250, 667-684. [CrossRef] [PubMed]

26. Esteva, F.J.; Hubbard-Lucey, V.M.; Tang, J.; Pusztai, L. Immunotherapy and targeted therapy combinations in metastatic breast cancer. Lancet Oncol. 2019, 20, e175-e186. [CrossRef]

27. Davis, A.A.; Patel, V.G. The role of PD-L1 expression as a predictive biomarker: An analysis of all US Food and Drug Administration (FDA) approvals of immune checkpoint inhibitors. J. Immunother. Cancer 2019, 7, 278. [CrossRef] [PubMed]

28. Wilky, B.A. Immune checkpoint inhibitors: The linchpins of modern immunotherapy. Immunol. Rev. 2019, 290, 6-23. [CrossRef] [PubMed]

29. Cimino-Mathews, A.; Foote, J.B.; Emens, L.A. Immune targeting in breast cancer. Oncology 2015, 29, 375-385.

30. Bertucci, F.; Goncalves, A. Immunotherapy in Breast Cancer: The Emerging Role of PD-1 and PD-L1. Curr. Oncol. Rep. 2017, 19, 64. [CrossRef] [PubMed]

31. Peg, V.; Lopez-Garcia, M.A.; Comerma, L.; Peiro, G.; Garcia-Caballero, T.; Lopez, A.C.; Suarez-Gauthier, A.; Ruiz, I.; Rojo, F. PD-L1 testing based on the SP142 antibody in metastatic triple-negative breast cancer: Summary of an expert round-table discussion. Future Oncol. 2021, 17, 1209-1218. [CrossRef] [PubMed]

32. Zou, Y.; Hu, X.; Zheng, S.; Yang, A.; Li, X.; Tang, H.; Kong, Y.; Xie, X. Discordance of immunotherapy response predictive biomarkers between primary lesions and paired metastases in tumours: A systematic review and meta-analysis. EBioMedicine 2021, 63, 103137. [CrossRef] [PubMed]

33. Zou, Y.; Zou, X.; Zheng, S.; Tang, H.; Zhang, L.; Liu, P.; Xie, X. Efficacy and predictive factors of immune checkpoint inhibitors in metastatic breast cancer: A systematic review and meta-analysis. Ther. Adv. Med. Oncol. 2020, 12, 1758835920940928. [CrossRef]

34. Quintela-Fandino, M.; Holgado, E.; Manso, L.; Morales, S.; Bermejo, B.; Colomer, R.; Apala, J.V.; Blanco, R.; Munoz, M.; Caleiras, E.; et al. Immuno-priming durvalumab with bevacizumab in HER2-negative advanced breast cancer: A pilot clinical trial. Breast Cancer Res. 2020, 22, 124. [CrossRef] [PubMed]

35. Yuan, C.; Liu, Z.; Yu, Q.; Wang, X.; Bian, M.; Yu, Z.; Yu, J. Expression of PD-1/PD-L1 in primary breast tumours and metastatic axillary lymph nodes and its correlation with clinicopathological parameters. Sci. Rep. 2019, 9, 14356. [CrossRef] [PubMed]

36. Dirix, L.Y.; Takacs, I.; Jerusalem, G.; Nikolinakos, P.; Arkenau, H.T.; Forero-Torres, A.; Boccia, R.; Lippman, M.E.; Somer, R.; Smakal, M.; et al. Avelumab, an anti-PD-L1 antibody, in patients with locally advanced or metastatic breast cancer: A phase $1 \mathrm{~b}$ JAVELIN Solid Tumor study. Breast Cancer Res. Treat. 2018, 167, 671-686. [CrossRef] [PubMed]

37. Erber, R.; Hartmann, A. Understanding PD-L1 Testing in Breast Cancer: A Practical Approach. Breast Care 2020, 15, 481-490. [CrossRef]

38. Adams, S.; Loi, S.; Toppmeyer, D.; Cescon, D.W.; De Laurentiis, M.; Nanda, R.; Winer, E.P.; Mukai, H.; Tamura, K.; Armstrong, A.; et al. Pembrolizumab monotherapy for previously untreated, PD-L1-positive, metastatic triple-negative breast cancer: Cohort $\mathrm{B}$ of the phase II KEYNOTE-086 study. Ann. Oncol. 2019, 30, 405-411. [CrossRef]

39. Adams, S.; Diamond, J.R.; Hamilton, E.; Pohlmann, P.R.; Tolaney, S.M.; Chang, C.W.; Zhang, W.; Iizuka, K.; Foster, P.G.; Molinero, L.; et al. Atezolizumab Plus nab-Paclitaxel in the Treatment of Metastatic Triple-Negative Breast Cancer With 2-Year Survival Follow-up: A Phase 1b Clinical Trial. JAMA Oncol. 2019, 5, 334-342. [CrossRef]

40. Alves, A.M.; Paredes, J.; Schmitt, F. Expression of PD-L1 in primary breast carcinoma and lymph node metastases. Surg. Exp. Pathol. 2019, 2, 7. [CrossRef]

41. Cimino-Mathews, A.; Thompson, E.; Taube, J.M.; Ye, X.; Lu, Y.; Meeker, A.; Xu, H.; Sharma, R.; Lecksell, K.; Cornish, T.C.; et al. PD-L1 (B7-H1) expression and the immune tumor microenvironment in primary and metastatic breast carcinomas. Hum. Pathol. 2016, 47, 52-63. [CrossRef]

42. Domchek, S.M.; Postel-Vinay, S.; Im, S.A.; Park, Y.H.; Delord, J.P.; Italiano, A.; Alexandre, J.; You, B.; Bastian, S.; Krebs, M.G.; et al. Olaparib and durvalumab in patients with germline BRCA-mutated metastatic breast cancer (MEDIOLA): An open-label, multicentre, phase 1/2, basket study. Lancet Oncol. 2020, 21, 1155-1164. [CrossRef]

43. Duchnowska, R.; Peksa, R.; Radecka, B.; Mandat, T.; Trojanowski, T.; Jarosz, B.; Czartoryska-Arlukowicz, B.; Olszewski, W.P.; Och, W.; Kalinka-Warzocha, E.; et al. Immune response in breast cancer brain metastases and their microenvironment: The role of the PD-1/PD-L axis. Breast Cancer Res. 2016, 18, 43. [CrossRef] [PubMed] 
44. Emens, L.A.; Esteva, F.J.; Beresford, M.; Saura, C.; De Laurentiis, M.; Kim, S.B.; Im, S.A.; Wang, Y.; Salgado, R.; Mani, A.; et al. Trastuzumab emtansine plus atezolizumab versus trastuzumab emtansine plus placebo in previously treated, HER2-positive advanced breast cancer (KATE2): A phase 2, multicentre, randomised, double-blind trial. Lancet Oncol. 2020, 21, $1283-1295$. [CrossRef]

45. Emens, L.A.; Cruz, C.; Eder, J.P.; Braiteh, F.; Chung, C.; Tolaney, S.M.; Kuter, I.; Nanda, R.; Cassier, P.A.; Delord, J.P.; et al. Long-term Clinical Outcomes and Biomarker Analyses of Atezolizumab Therapy for Patients With Metastatic Triple-Negative Breast Cancer: A Phase 1 Study. JAMA Oncol. 2019, 5, 74-82. [CrossRef]

46. Erol, T.; Imamoglu, N.E.; Aydin, B.; Taskiran, Z.E.; Esendagli, G.; Kosemehmetoglu, K.; Baykal, A. Primary tumor resection for initially staged IV breast cancer: An emphasis on programmed death-ligand 1 expression, promoter methylation status, and survival. Medicine 2019, 98, e16773. [CrossRef]

47. Han, B.; Dong, L.; Zhou, J.; Yang, Y.; Guo, J.; Xuan, Q.; Gao, K.; Xu, Z.; Lei, W.; Wang, J.; et al. The clinical implication of soluble PD-L1 (sPD-L1) in patients with breast cancer and its biological function in regulating the function of T lymphocyte. Cancer Immunol. Immunother. 2021, 70, 2893-2909. [CrossRef] [PubMed]

48. Loi, S.; Giobbie-Hurder, A.; Gombos, A.; Bachelot, T.; Hui, R.; Curigliano, G.; Campone, M.; Biganzoli, L.; Bonnefoi, H.; Jerusalem, G.; et al. Pembrolizumab plus trastuzumab in trastuzumab-resistant, advanced, HER2-positive breast cancer (PANACEA): A single-arm, multicentre, phase 1b-2 trial. Lancet Oncol. 2019, 20, 371-382. [CrossRef]

49. Manson, Q.F.; Schrijver, W.; Ter Hoeve, N.D.; Moelans, C.B.; van Diest, P.J. Frequent discordance in PD-1 and PD-L1 expression between primary breast tumors and their matched distant metastases. Clin. Exp. Metastasis 2019, 36, 29-37. [CrossRef]

50. Mitchell, T.C.; Hamid, O.; Smith, D.C.; Bauer, T.M.; Wasser, J.S.; Olszanski, A.J.; Luke, J.J.; Balmanoukian, A.S.; Schmidt, E.V.; Zhao, Y.; et al. Epacadostat Plus Pembrolizumab in Patients With Advanced Solid Tumors: Phase I Results from a Multicenter, Open-Label Phase I/II Trial (ECHO-202/KEYNOTE-037). J. Clin. Oncol. 2018, 36, 3223-3230. [CrossRef] [PubMed]

51. Nanda, R.; Chow, L.Q.; Dees, E.C.; Berger, R.; Gupta, S.; Geva, R.; Pusztai, L.; Pathiraja, K.; Aktan, G.; Cheng, J.D.; et al. Pembrolizumab in Patients With Advanced Triple-Negative Breast Cancer: Phase Ib KEYNOTE-012 Study. J. Clin. Oncol. 2016, 34, 2460-2467. [CrossRef] [PubMed]

52. Ogiya, R.; Niikura, N.; Kumaki, N.; Bianchini, G.; Kitano, S.; Iwamoto, T.; Hayashi, N.; Yokoyama, K.; Oshitanai, R.; Terao, M.; et al. Comparison of tumor-infiltrating lymphocytes between primary and metastatic tumors in breast cancer patients. Cancer Sci. 2016, 107, 1730-1735. [CrossRef]

53. Rugo, H.S.; Delord, J.P.; Im, S.A.; Ott, P.A.; Piha-Paul, S.A.; Bedard, P.L.; Sachdev, J.; Le Tourneau, C.; van Brummelen, E.M.J.; Varga, A.; et al. Safety and Antitumor Activity of Pembrolizumab in Patients with Estrogen Receptor-Positive/Human Epidermal Growth Factor Receptor 2-Negative Advanced Breast Cancer. Clin. Cancer Res. 2018, 24, 2804-2811. [CrossRef] [PubMed]

54. Santa-Maria, C.A.; Kato, T.; Park, J.H.; Kiyotani, K.; Rademaker, A.; Shah, A.N.; Gross, L.; Blanco, L.Z.; Jain, S.; Flaum, L.; et al. A pilot study of durvalumab and tremelimumab and immunogenomic dynamics in metastatic breast cancer. Oncotarget 2018, 9 , 18985-18996. [CrossRef]

55. Schott, D.S.; Pizon, M.; Pachmann, U.; Pachmann, K. Sensitive detection of PD-L1 expression on circulating epithelial tumor cells (CETCs) could be a potential biomarker to select patients for treatment with PD-1/PD-L1 inhibitors in early and metastatic solid tumors. Oncotarget 2017, 8, 72755-72772. [CrossRef] [PubMed]

56. Szekely, B.; Bossuyt, V.; Li, X.; Wali, V.B.; Patwardhan, G.A.; Frederick, C.; Silber, A.; Park, T.; Harigopal, M.; Pelekanou, V.; et al. Immunological differences between primary and metastatic breast cancer. Ann. Oncol. 2018, 29, 2232-2239. [CrossRef]

57. Tawfik, O.; Kimler, B.F.; Karnik, T.; Shehata, P. Clinicopathological correlation of PD-L1 expression in primary and metastatic breast cancer and infiltrating immune cells. Hum. Pathol. 2018, 80, 170-178. [CrossRef]

58. Tolaney, S.M.; Kalinsky, K.; Kaklamani, V.G.; D’Adamo, D.R.; Aktan, G.; Tsai, M.L.; O’Regan, R.M.; Kaufman, P.A.; Wilks, S.T.; Andreopoulou, E.; et al. Eribulin Plus Pembrolizumab in Patients with Metastatic Triple-Negative Breast Cancer (ENHANCE 1): A Phase Ib/II Study. Clin. Cancer Res. 2021, 27, 3061-3068. [CrossRef] [PubMed]

59. Voorwerk, L.; Slagter, M.; Horlings, H.M.; Sikorska, K.; van de Vijver, K.K.; de Maaker, M.; Nederlof, I.; Kluin, R.J.C.; Warren, S.; Ong, S.; et al. Immune induction strategies in metastatic triple-negative breast cancer to enhance the sensitivity to PD-1 blockade: The TONIC trial. Nat. Med. 2019, 25, 920-928. [CrossRef]

60. Yazdanpanah, P.; Alavianmehr, A.; Ghaderi, A.; Monabati, A.; Montazer, M.; Tahmasbi, K.; Farjadian, S. PD-L1 expression in tumor lesions and soluble PD-L1 serum levels in patients with breast cancer: TNBC versus TPBC. Breast Dis. 2021, 40, 43-50. [CrossRef]

61. Vaught, J.B. Blood collection, shipment, processing, and storage. Cancer Epidemiol. Biomark. Prev. 2006, 15, 1582-1584. [CrossRef] [PubMed]

62. Pardoll, D.M. The blockade of immune checkpoints in cancer immunotherapy. Nat. Rev. Cancer 2012, 12, 252-264. [CrossRef] [PubMed]

63. Agata, Y.; Kawasaki, A.; Nishimura, H.; Ishida, Y.; Tsubata, T.; Yagita, H.; Honjo, T. Expression of the PD-1 antigen on the surface of stimulated mouse $\mathrm{T}$ and B lymphocytes. Int. Immunol. 1996, 8, 765-772. [CrossRef] [PubMed]

64. Dong, H.; Zhu, G.; Tamada, K.; Chen, L. B7-H1, a third member of the B7 family, co-stimulates T-cell proliferation and interleukin10 secretion. Nat. Med. 1999, 5, 1365-1369. [CrossRef]

65. Patel, S.P.; Kurzrock, R. PD-L1 Expression as a Predictive Biomarker in Cancer Immunotherapy. Mol. Cancer Ther. 2015, 14, 847-856. [CrossRef] 
66. Vennapusa, B.; Baker, B.; Kowanetz, M.; Boone, J.; Menzl, I.; Bruey, J.M.; Fine, G.; Mariathasan, S.; McCaffery, I.; Mocci, S.; et al. Development of a PD-L1 Complementary Diagnostic Immunohistochemistry Assay (SP142) for Atezolizumab. Appl. Immunohistochem. Mol. Morphol. 2019, 27, 92-100. [CrossRef] [PubMed]

67. Ghebeh, H.; Barhoush, E.; Tulbah, A.; Elkum, N.; Al-Tweigeri, T.; Dermime, S. FOXP3+ Tregs and B7-H1+/PD-1+ T lymphocytes co-infiltrate the tumor tissues of high-risk breast cancer patients: Implication for immunotherapy. BMC Cancer $2008,8,57$. [CrossRef] [PubMed]

68. Mittendorf, E.A.; Philips, A.V.; Meric-Bernstam, F.; Qiao, N.; Wu, Y.; Harrington, S.; Su, X.; Wang, Y.; Gonzalez-Angulo, A.M.; Akcakanat, A.; et al. PD-L1 expression in triple-negative breast cancer. Cancer Immunol. Res. 2014, 2, 361-370. [CrossRef]

69. Gatalica, Z.; Snyder, C.; Maney, T.; Ghazalpour, A.; Holterman, D.A.; Xiao, N.; Overberg, P.; Rose, I.; Basu, G.D.; Vranic, S.; et al. Programmed cell death 1 (PD-1) and its ligand (PD-L1) in common cancers and their correlation with molecular cancer type. Cancer Epidemiol. Biomark. Prev. 2014, 23, 2965-2970. [CrossRef]

70. Muenst, S.; Schaerli, A.R.; Gao, F.; Daster, S.; Trella, E.; Droeser, R.A.; Muraro, M.G.; Zajac, P.; Zanetti, R.; Gillanders, W.E.; et al. Expression of programmed death ligand 1 (PD-L1) is associated with poor prognosis in human breast cancer. Breast Cancer Res. Treat. 2014, 146, 15-24. [CrossRef]

71. Garcia-Aranda, M.; Redondo, M. Immunotherapy: A Challenge of Breast Cancer Treatment. Cancers 2019, 11, 1822. [CrossRef]

72. Rozali, E.N.; Hato, S.V.; Robinson, B.W.; Lake, R.A.; Lesterhuis, W.J. Programmed death ligand 2 in cancer-induced immune suppression. Clin. Dev. Immunol. 2012, 2012, 656340. [CrossRef] [PubMed]

73. Philips, E.A.; Garcia-Espana, A.; Tocheva, A.S.; Ahearn, I.M.; Adam, K.R.; Pan, R.; Mor, A.; Kong, X.P. The structural features that distinguish PD-L2 from PD-L1 emerged in placental mammals. J. Biol. Chem. 2020, 295, 4372-4380. [CrossRef]

74. Zak, K.M.; Grudnik, P.; Magiera, K.; Domling, A.; Dubin, G.; Holak, T.A. Structural Biology of the Immune Checkpoint Receptor PD-1 and Its Ligands PD-L1/PD-L2. Structure 2017, 25, 1163-1174. [CrossRef] [PubMed]

75. Latchman, Y.; Wood, C.R.; Chernova, T.; Chaudhary, D.; Borde, M.; Chernova, I.; Iwai, Y.; Long, A.J.; Brown, J.A.; Nunes, R.; et al. PD-L2 is a second ligand for PD-1 and inhibits T cell activation. Nat. Immunol. 2001, 2, 261-268. [CrossRef] [PubMed]

76. Chen, Y.; Wang, Q.; Shi, B.; Xu, P.; Hu, Z.; Bai, L.; Zhang, X. Development of a sandwich ELISA for evaluating soluble PD-L1 (CD274) in human sera of different ages as well as supernatants of PD-L1+ cell lines. Cytokine 2011, 56, 231-238. [CrossRef]

77. Orme, J.J.; Jazieh, K.A.; Xie, T.; Harrington, S.; Liu, X.; Ball, M.; Madden, B.; Charlesworth, M.C.; Azam, T.U.; Lucien, F.; et al. ADAM10 and ADAM17 cleave PD-L1 to mediate PD-(L)1 inhibitor resistance. Oncoimmunology 2020, 9, 1744980. [CrossRef]

78. Li, Y.; Cui, X.; Yang, Y.J.; Chen, Q.Q.; Zhong, L.; Zhang, T.; Cai, R.L.; Miao, J.Y.; Yu, S.C.; Zhang, F. Serum sPD-1 and sPD-L1 as Biomarkers for Evaluating the Efficacy of Neoadjuvant Chemotherapy in Triple-Negative Breast Cancer Patients. Clin. Breast Cancer 2019, 19, 326-332.e1. [CrossRef]

79. Lawson, N.L.; Dix, C.I.; Scorer, P.W.; Stubbs, C.J.; Wong, E.; Hutchinson, L.; McCall, E.J.; Schimpl, M.; DeVries, E.; Walker, J.; et al. Mapping the binding sites of antibodies utilized in programmed cell death ligand-1 predictive immunohistochemical assays for use with immuno-oncology therapies. Mod. Pathol. 2020, 33, 518-530. [CrossRef] [PubMed]

80. Schwamborn, K.; Ammann, J.U.; Knuchel, R.; Hartmann, A.; Baretton, G.; Lasitschka, F.; Schirmacher, P.; Braunschweig, T.; Tauber, R.; Erlmeier, F.; et al. Multicentric analytical comparability study of programmed death-ligand 1 expression on tumor-infiltrating immune cells and tumor cells in urothelial bladder cancer using four clinically developed immunohistochemistry assays. Virchows Arch. 2019, 475, 599-608. [CrossRef]

81. Scott, M.; Scorer, P.; Barker, C.; Al-Masri, H. Comparison of patient populations identified by different PD-L1 assays in in triple-negative breast cancer (TNBC). Ann. Oncol. 2019, 30, iii4. [CrossRef]

82. Tsao, M.S.; Kerr, K.M.; Kockx, M.; Beasley, M.B.; Borczuk, A.C.; Botling, J.; Bubendorf, L.; Chirieac, L.; Chen, G.; Chou, T.Y.; et al. PD-L1 Immunohistochemistry Comparability Study in Real-Life Clinical Samples: Results of Blueprint Phase 2 Project. J. Thorac. Oncol. 2018, 13, 1302-1311. [CrossRef]

83. Liu, Y.; Zugazagoitia, J.; Ahmed, F.S.; Henick, B.S.; Gettinger, S.N.; Herbst, R.S.; Schalper, K.A.; Rimm, D.L. Immune Cell PD-L1 Colocalizes with Macrophages and Is Associated with Outcome in PD-1 Pathway Blockade Therapy. Clin. Cancer Res. 2020, 26, 970-977. [CrossRef]

84. Schats, K.A.; Van Vre, E.A.; Boeckx, C.; De Bie, M.; Schrijvers, D.M.; Neyns, B.; De Meester, I.; Kockx, M.M. Optimal Evaluation of Programmed Death Ligand-1 on Tumor Cells Versus Immune Cells Requires Different Detection Methods. Arch. Pathol. Lab. Med. 2018, 142, 982-991. [CrossRef] [PubMed]

85. Scheel, A.H.; Dietel, M.; Heukamp, L.C.; Johrens, K.; Kirchner, T.; Reu, S.; Ruschoff, J.; Schildhaus, H.U.; Schirmacher, P.; Tiemann, M.; et al. Harmonized PD-L1 immunohistochemistry for pulmonary squamous-cell and adenocarcinomas. Mod. Pathol. 2016, 29, 1165-1172. [CrossRef]

86. Rimm, D.L.; Han, G.; Taube, J.M.; Yi, E.S.; Bridge, J.A.; Flieder, D.B.; Homer, R.; Roden, A.C.; Hirsch, F.R.; Wistuba, I.I.; et al. Reanalysis of the NCCN PD-L1 companion diagnostic assay study for lung cancer in the context of PD-L1 expression findings in triple-negative breast cancer. Breast Cancer Res. 2019, 21, 72. [CrossRef]

87. Velcheti, V.; Patwardhan, P.D.; Liu, F.X.; Chen, X.; Cao, X.; Burke, T. Real-world PD-L1 testing and distribution of PD-L1 tumor expression by immunohistochemistry assay type among patients with metastatic non-small cell lung cancer in the United States. PLoS ONE 2018, 13, e0206370. [CrossRef] [PubMed]

88. Ramos-Vara, J.A.; Miller, M.A. When tissue antigens and antibodies get along: Revisiting the technical aspects of immunohistochemistry-the red, brown, and blue technique. Vet. Pathol. 2014, 51, 42-87. [CrossRef] [PubMed] 
89. Ramos-Vara, J.A. Technical aspects of immunohistochemistry. Vet. Pathol. 2005, 42, 405-426. [CrossRef] [PubMed]

90. Sturgeon, C.M.; Duffy, M.J.; Stenman, U.H.; Lilja, H.; Brunner, N.; Chan, D.W.; Babaian, R.; Bast, R.C., Jr.; Dowell, B.; Esteva, F.J.; et al. National Academy of Clinical Biochemistry laboratory medicine practice guidelines for use of tumor markers in testicular, prostate, colorectal, breast, and ovarian cancers. Clin. Chem. 2008, 54, e11-e79. [CrossRef]

91. Koivunen, M.E.; Krogsrud, R.L. Principles of Immunochemical Techniques Used in Clinical Laboratories. Lab. Med. 2006, 37, 490-497. [CrossRef]

92. Khoshfetrat, S.M.; Bagheri, H.; Mehrgardi, M.A. Visual electrochemiluminescence biosensing of aflatoxin M1 based on luminolfunctionalized, silver nanoparticle-decorated graphene oxide. Biosens. Bioelectron. 2018, 100, 382-388. [CrossRef] [PubMed]

93. Miao, W. Electrogenerated chemiluminescence and its biorelated applications. Chem. Rev. 2008, 108, 2506-2553. [CrossRef]

94. Richter, M.M. Electrochemiluminescence (ECL). Chem. Rev. 2004, 104, 3003-3036. [CrossRef]

95. Fahnrich, K.A.; Pravda, M.; Guilbault, G.G. Recent applications of electrogenerated chemiluminescence in chemical analysis. Talanta 2001, 54, 531-559. [CrossRef]

96. Hicks, J.M. Fluorescence immunoassay. Hum. Pathol. 1984, 15, 112-116. [CrossRef]

97. Jeong, S.; Park, M.J.; Song, W.; Kim, H.S. Current immunoassay methods and their applications to clinically used biomarkers of breast cancer. Clin. Biochem. 2020, 78, 43-57. [CrossRef] [PubMed]

98. Bustin, S.A.; Mueller, R. Real-time reverse transcription PCR (qRT-PCR) and its potential use in clinical diagnosis. Clin. Sci. 2005, 109, 365-379. [CrossRef] [PubMed]

99. Freeman, W.M.; Walker, S.J.; Vrana, K.E. Quantitative RT-PCR: Pitfalls and potential. Biotechniques 1999, 26, 112-125. [CrossRef]

100. Li, H.; McCormac, M.A.; Estes, R.W.; Sefers, S.E.; Dare, R.K.; Chappell, J.D.; Erdman, D.D.; Wright, P.F.; Tang, Y.W. Simultaneous detection and high-throughput identification of a panel of RNA viruses causing respiratory tract infections. J. Clin. Microbiol. 2007, 45, 2105-2109. [CrossRef]

101. Cree, I.A.; Booton, R.; Cane, P.; Gosney, J.; Ibrahim, M.; Kerr, K.; Lal, R.; Lewanski, C.; Navani, N.; Nicholson, A.G.; et al. PD-L1 testing for lung cancer in the UK: Recognizing the challenges for implementation. Histopathology 2016, 69, 177-186. [CrossRef]

102. Eckstein, M.; Cimadamore, A.; Hartmann, A.; Lopez-Beltran, A.; Cheng, L.; Scarpelli, M.; Montironi, R.; Gevaert, T. PD-L1 assessment in urothelial carcinoma: A practical approach. Ann. Transl. Med. 2019, 7, 690. [CrossRef]

103. Herbst, R.S.; Baas, P.; Kim, D.W.; Felip, E.; Perez-Gracia, J.L.; Han, J.Y.; Molina, J.; Kim, J.H.; Arvis, C.D.; Ahn, M.J.; et al. Pembrolizumab versus docetaxel for previously treated, PD-L1-positive, advanced non-small-cell lung cancer (KEYNOTE-010): A randomised controlled trial. Lancet 2016, 387, 1540-1550. [CrossRef]

104. Guo, H.; Ding, Q.; Gong, Y.; Gilcrease, M.Z.; Zhao, M.; Zhao, J.; Sui, D.; Wu, Y.; Chen, H.; Liu, H.; et al. Comparison of three scoring methods using the FDA-approved 22C3 immunohistochemistry assay to evaluate PD-L1 expression in breast cancer and their association with clinicopathologic factors. Breast Cancer Res. 2020, 22, 69. [CrossRef] [PubMed]

105. Rugo, H.S.; Loi, S.; Adams, S.; Schmid, P.; Schneeweiss, A.; Barrios, C.H.; Iwata, H.; Dieras, V.C.; Winer, E.P.; Kockx, M.; et al. Performance of PD-L1 immunohistochemistry (IHC) assays in unresectable locally advanced or metastatic triple-negative breast cancer (mTNBC): Post-hoc analysis of IMpassion130. Ann. Oncol. 2019, 30, v858-v859. [CrossRef]

106. Grandal, B.; Mangiardi-Veltin, M.; Laas, E.; Lae, M.; Meseure, D.; Bataillon, G.; El-Alam, E.; Darrigues, L.; Dumas, E.; Daoud, E.; et al. PD-L1 Expression after Neoadjuvant Chemotherapy in Triple-Negative Breast Cancers Is Associated with Aggressive Residual Disease, Suggesting a Potential for Immunotherapy. Cancers 2021, 13, 746. [CrossRef] [PubMed]

107. Alunni-Fabbroni, M.; Sandri, M.T. Circulating tumour cells in clinical practice: Methods of detection and possible characterization. Methods 2010, 50, 289-297. [CrossRef]

108. Danova, M.; Delfanti, S.; Manzoni, M.; Mariucci, S. Tissue and soluble biomarkers in breast cancer and their applications: Ready to use? J. Natl. Cancer Inst. Monogr. 2011, 2011, 75-78. [CrossRef]

109. Papadaki, M.A.; Koutsopoulos, A.V.; Tsoulfas, P.G.; Lagoudaki, E.; Aggouraki, D.; Monastirioti, A.; Koutoulaki, C.; Apostolopoulou, C.A.; Merodoulaki, A.C.; Papadaki, C.; et al. Clinical Relevance of Immune Checkpoints on Circulating Tumor Cells in Breast Cancer. Cancers 2020, 12, 376. [CrossRef] [PubMed]

110. Polioudaki, H.; Mala, A.; Gkimprixi, E.; Papadaki, M.A.; Chantziou, A.; Tzardi, M.; Mavroudis, D.; Agelaki, S.; Theodoropoulos, P.A. Epithelial/Mesenchymal Characteristics and PD-L1 Co-Expression in CTCs of Metastatic Breast Cancer Patients Treated with Eribulin: Correlation with Clinical Outcome. Cancers 2020, 12, 3735. [CrossRef]

111. Sakuishi, K.; Apetoh, L.; Sullivan, J.M.; Blazar, B.R.; Kuchroo, V.K.; Anderson, A.C. Targeting Tim-3 and PD-1 pathways to reverse $\mathrm{T}$ cell exhaustion and restore anti-tumor immunity. J. Exp. Med. 2010, 207, 2187-2194. [CrossRef]

112. Stagg, J.; Divisekera, U.; McLaughlin, N.; Sharkey, J.; Pommey, S.; Denoyer, D.; Dwyer, K.M.; Smyth, M.J. Anti-CD73 antibody therapy inhibits breast tumor growth and metastasis. Proc. Natl. Acad. Sci. USA 2010, 107, 1547-1552. [CrossRef] [PubMed]

113. Allard, B.; Turcotte, M.; Stagg, J. Targeting CD73 and downstream adenosine receptor signaling in triple-negative breast cancer. Expert Opin. Ther. Targets 2014, 18, 863-881. [CrossRef] [PubMed]

114. Loi, S.; Pommey, S.; Haibe-Kains, B.; Beavis, P.A.; Darcy, P.K.; Smyth, M.J.; Stagg, J. CD73 promotes anthracycline resistance and poor prognosis in triple negative breast cancer. Proc. Natl. Acad. Sci. USA 2013, 110, 11091-11096. [CrossRef]

115. Cerbelli, B.; Scagnoli, S.; Mezi, S.; De Luca, A.; Pisegna, S.; Amabile, M.I.; Roberto, M.; Fortunato, L.; Costarelli, L.; Pernazza, A.; et al. Tissue Immune Profile: A Tool to Predict Response to Neoadjuvant Therapy in Triple Negative Breast Cancer. Cancers 2020, 12, 2648. [CrossRef] [PubMed] 
116. Matikas, A.; Zerdes, I.; Lovrot, J.; Richard, F.; Sotiriou, C.; Bergh, J.; Valachis, A.; Foukakis, T. Prognostic Implications of PD-L1 Expression in Breast Cancer: Systematic Review and Meta-analysis of Immunohistochemistry and Pooled Analysis of Transcriptomic Data. Clin. Cancer Res. 2019, 25, 5717-5726. [CrossRef] [PubMed]

117. Adams, S.; Schmid, P.; Rugo, H.S.; Winer, E.P.; Loirat, D.; Awada, A.; Cescon, D.W.; Iwata, H.; Campone, M.; Nanda, R.; et al. Pembrolizumab monotherapy for previously treated metastatic triple-negative breast cancer: Cohort A of the phase II KEYNOTE-086 study. Ann. Oncol. 2019, 30, 397-404. [CrossRef] [PubMed] 